UNIVERSIDADE ESTADUAL PAULISTA “JULIO DE MESQUITA FILHO” FACULDADE DE CIÊNCIAS AGRÔNOMICAS CÂMPUS DE BOTUCATU

\title{
HERANÇA DA RESISTÊNCIA A OÍDIO EM ERVILHA E ASPECTOS RELACIONADOS À PATOGÊNESE
}

RICARDO LIMA DOS SANTOS

Dissertação apresentada à Faculdade de Ciências Agronômicas da UNESP - Campus de Botucatu, para obtenção do título de Mestre em Agronomia (Horticultura).

BOTUCATU - SP

Fevereiro - 2010 
UNIVERSIDADE ESTADUAL PAULISTA “JULIO DE MESQUITA FILHO” FACULDADE DE CIÊNCIAS AGRÔNOMICAS CÂMPUS DE BOTUCATU

\section{HERANÇA DA RESISTÊNCIA A OÍDIO EM ERVILHA E ASPECTOS RELACIONADOS À PATOGÊNESE}

\section{RICARDO LIMA DOS SANTOS}

Engenheiro Agrônomo

ORIENTADOR: MARCELO AGENOR PAVAN

CO-ORIENTADOR: NORBERTO DA SILVA

Dissertação apresentada à Faculdade de Ciências Agronômicas da UNESP - Campus de Botucatu, para obtenção do título de Mestre em Agronomia (Horticultura)

BOTUCATU - SP

Fevereiro - 2010 
FICHA CATALOGRÁpICA ELABORADA PALA SAÇÃo TÉCNICA DE AQUISIÇ̃̃o E TRATAMBNTO DA INFORMAÇÃo - SARVIÇO TÍCNICO DE BIBLIOTECA E DOCUIUNTAÇẢ́O - UNESP - FCA - LAGEADO - BOTUCATU (SP)

Santos, Ricardo Lima dos, 1984Herança da resistência a oídio em ervilha e aspectos relacionados à patogênese / Ricardo Lima dos Santos. Botucatu : [s.n.], 2010. vi, 52 f. : tabs., fots. color.

Dissertação (Mestrado) - Universidade Estadual Paulista, Faculdade de Ciências Agronômicas, Botucatu, 2010 Orientador: Marcelo Agenor Pavan Co-orientador: Norberto da Silva Inclui bibliografia.

1. Erysiphe pisi. 2. Resistência genética. 3. Interação patógeno-hospedeiro. 4. MK-10. 5. Histologia. I. Pavan, Marcelo Agenor. II. Silva, Norberto da. III. Universidade Estadual Paulista "Júlio de Mesquita Filho" (Campus de Botucatu). Faculdade de Ciências Agronômicas. TV. Título. 


\section{UNIVERSIDADE ESTADUAL PAULISTA “JÚLIO DE MESQUITA FILHO”}

FACULDADE DE CIÊNCIAS AGRONÔMICAS

CAMPUS DE BOTUCATU

CERTIFICADO DE APROVAÇÃO

TÍTULO: "HERANÇA DA RESistÊnCIA A OÍDIO EM ERVILHA E ASPECTOS RELACIONADOS À PATOGÊNESE".

ALUNO: RICARDO LIMA DOS SANTOS

ORIENTADOR: PROF. DR. MARCELO AGENOR PAVAN

CO-ORIENTADOR: PROF. DR. NORBERTO DA SILVA

Aprovado pela Comissão Examinadora

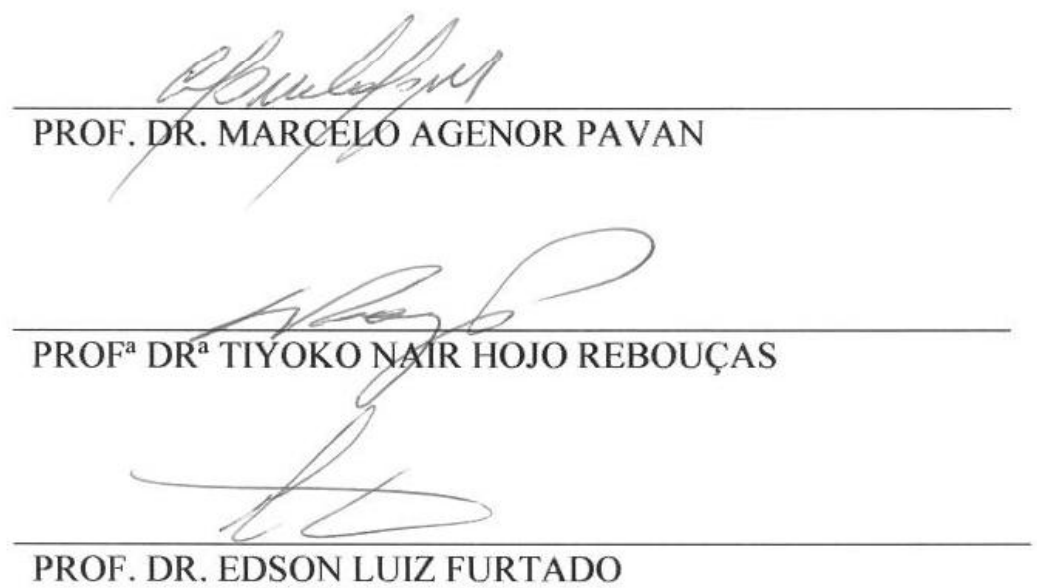

Data da Realização: 05 de Fevereiro de 2010. 


\section{AGRADECIMENTOS}

A Deus, por me guiar sempre.

Aos meus pais, Evaldo e Arlete pelo apoio e confiança incondicional.

A minha irmã, Camila, que apesar da distância, está sempre ao meu lado.

À Universidade Estadual Paulista "Julio Mesquita Filho" pela oportunidade de realização do curso.

Ao meu orientador, Prof. Dr. Marcelo Agenor Pavan, pela orientação, paciência e boa vontade sempre.

Ao meu co-orientador, Norberto da Silva, pelos incessantes ensinamentos, atenção, simplicidade e apoio ao longo do curso.

Ao amigo e acadêmico em Agronomia, Leandro Fumes, pela amizade e colaboração durante os experimentos.

A professora Silvia Renata Wilcken pela ajuda com o microscópio DIC.

Ao professor Edson Luiz Furtado pelas dúvidas esclarecidas.

A professora Rumy Goto, pela amizade.

Aos funcionários de São Manoel: Nilton, Luís, Daniel e todos os demais, que não mediram esforços para a execução e sucesso dos trabalhos realizados.

A todos os professores e funcionários do Departamento de Horticultura, que de alguma forma colaboraram para o sucesso desse trabalho.

Aos funcionários da biblioteca Prof. Paulo de Carvalho Mattos.

A toda minha família pelo incentivo.

Aos colegas Bárbara, Edvar, Manoel, Karol (Pará), Amanda, Maria Augusta (K-xa), Rosão, Adriana Tanaka, Mel, Anamaria, Marinês, Tatiana Mituti, Kelly Rocha, Mônika Fecury e Júlio, pela amizade e apoio.

Ao Conselho Nacional de Desenvolvimento e Pesquisa (CNPq) pela concessão da bolsa de estudos.

A todos que de alguma forma colaboraram para meu sucesso. 


\section{SUMÁRIO}

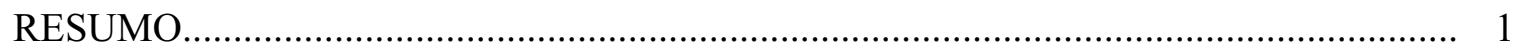

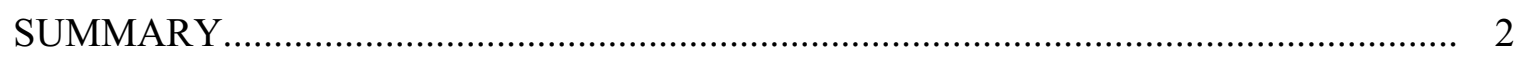

1. INTRODUÇÃO

2. REVISÃO DE LITERATURA.......................................................................... 5

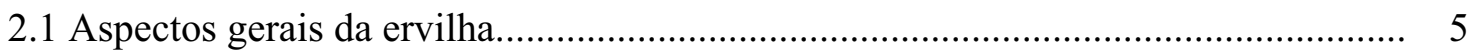

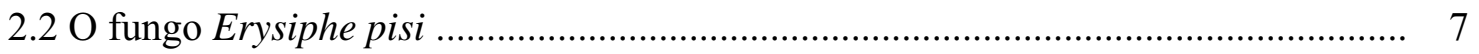

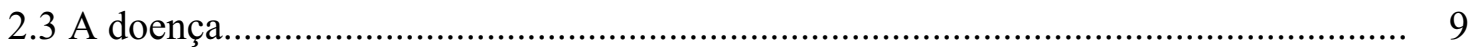

2.4 Resistência ao oídio em ervilha....................................................................... 11

2.5 Histologia da interação E. pisi - P. sativum........................................................ 16

3. MATERIAL E MÉTODOS.............................................................................. 19

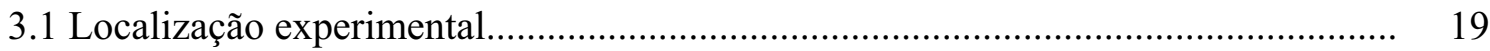

3.2 Estudo da herança da resistência ao Erysiphe pisi.................................................... 20

3.2.1Condução Experimental................................................................................... 21

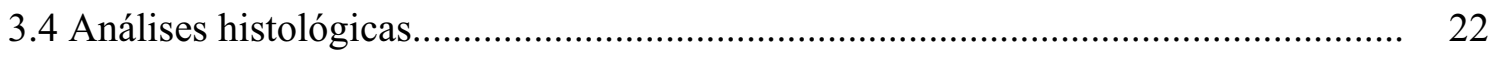

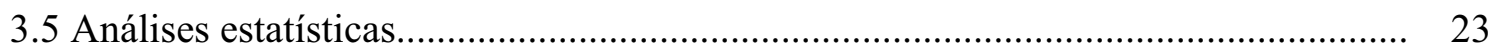

4. RESULTADOS E DISCUSSÃO....................................................................... 24

4.1 Estudo da herança da resistência ao Erysiphe pisi................................................ 24

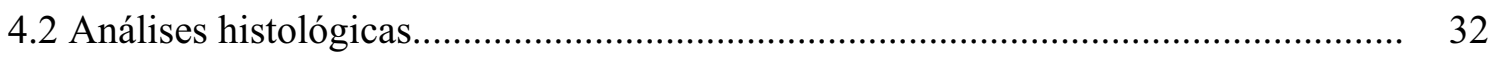

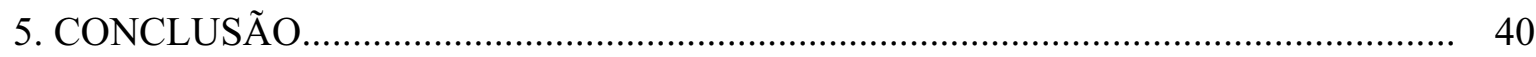

6. REFERÊNCIAS BIBLIOGRÁFICAS............................................................. 41 


\section{LISTA DE TABELAS}

1. Segregação para resistência ao oídio em ervilha da geração F2. São Manuel, $\mathrm{SP}-2009$

2. Segregação para os retrocruzamentos com progenitores resistentes e suscetíveis. São Manuel, SP - 2009.

3. Segregação para resistência ao oídio em ervilha da geração F3. São Manuel, SP - 2009

4. Valores médios dos estádios de desenvolvimento de E. pisi em populações F2 resistentes e suscetíveis ao oídio em ervilha. FCA-UNESP, Botucatu , SP - 2009. 


\section{LISTA DE FIGURAS}

1. Vista geral do Experimento em São Manoel-SP......................................................... 20

2. Torta de Flor Roxa infectada por E. pisi, FCA-UNESP, 2009................................... 35

3. Reação de hipersensibilidade (RH) em conídios germinados em folíolos de ervilha,

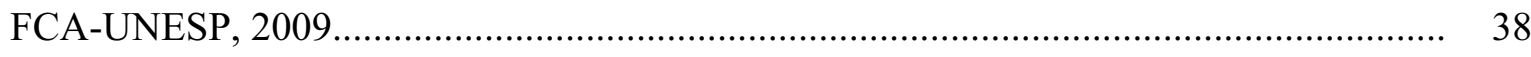




\section{HERANÇA DA RESISTÊNCIA A OÍDIO EM ERVILHA E ASPECTOS RELACIONADOS À PATOGÊNESE}

AUTOR: Ricardo Lima dos Santos

ORIENTADOR: Prof. Dr. Marcelo Agenor Pavan

CO-ORIENTADOR: Prof. Dr. Norberto da Silva

\section{RESUMO}

A ervilha (Pisum sativum L.) é um dos alimentos mais produzidos no mundo. Uma das principais doenças que ocorrem na cultura é o oídio, causada por Erysiphe pisi DC. O controle da doença tem sido realizado por meio de pulverizações com fungicidas, no entanto, o uso de cultivares resistentes deve ser pensado como uma alternativa viável e de efetivo controle no manejo da doença. O trabalho objetivou elucidar a herança da resistência ao oídio na cultivar de ervilha MK-10 e caracterizar alguns aspectos histológicos da infecção de E. pisi nessa cultivar. Para o estudo da herança, as gerações F1, F2, retrocuzamentos e geração F3 de MK-10 com duas populações suscetíveis foram avaliadas em ambiente protegido e a epidemia foi aberta. Nas avaliações histológicas, os seguintes parâmetros foram avaliados: \% de germinação dos conídios, \% de conídios germinados que formaram apressório, \% de conídios germinados com apressório que estabeleceram colônia (\% colonização) e número de haustórios por colônia. Para comparar as razões de segregação obtidas no estudo da herança da resistência, adotou-se o teste do Qui-quadrado $\left(X^{2}\right)$ e para os dados das análises histológicas, utilizou-se o teste Tukey a 5\% de probabilidade. Com base nas segregações obtidas no estudo da herança e nas análises histológicas realizadas, concluiu-se que a resistência de MK-10 ao oídio é devida a um par de alelos recessivos, provavelmente o erlerl e que a resistência é expressa na fase de pré-penetração, completada por uma morte celular localizada pós-penetração.

Palavras chave: Erysiphe pisi, resistência genética, interação patógeno-hospedeiro, MK-10, histologia. 


\section{INHERITANCE OF POWDERY MILDEW RESISTANCE IN PEA AND ASPECTS RELATIONSHIPS THE PATHOGENESIS. Botucatu, 2010, 52p. Dissertação (Mestrado} em Agronomia/Horticultura) - Faculdade de Ciências Agronômicas, Universidade Estadual Paulista.

Author: Ricardo Lima dos Santos

Adviser: Prof. Dr. Marcelo Agenor Pavan

Co-adviser: Prof. Dr. Norberto da Silva

\section{SUMMARY}

The pea (Pisum sativum L.) is the most produced foods in the world. One of the main diseases that occur in the culture is the powdery mildew, caused for Erysiphe pisi DC. The control of the disease has been carried through by means of sprayings with fungicides, however, the use to cultivars resistants must be thought as a viable alternative and of effective control about the handling of the disease. The work objectified to elucidate the inheritance of the resistance to powdery mildew in cultivar of pea MK-10 and to characterize some histological aspects of the infection of E. pisi in this cultivar. For the study of the inheritance, the F1, F2, generations, backcrosses and F3 generations of MK-10 with two susceptible populations had been evaluated in protected environment, the epidemic were open. In the histological evaluations, the following parameters had been evaluated: percentage of germination, percentage of germinated sporelings forming aprressorium, percentage of germinated sporelings with appressorium that established a colony (\% colonization) and number of haustoria for colony. To compare the gotten reasons of segregation in the study of the inheritance of the resistance, the test of Qui-square $\left(\mathrm{X}^{2}\right)$ was adopted and for the data of the histological analyses, the Tukey test was used $5 \%$ of probability. On the basis of the segregations gotten in the study of the inheritance and the carried through histological analyses, were concluded that the resistance of MK-10 to the powdery mildew must to a pair of recessive alleles probably erlerl and that the resistance is express in the pre-penetration phase, completed for a cellular death located post-penetration.

Keywords: Erysiphe pisi, genetic resistance, pathogen-host interaction, MK-10, histology 


\section{INTRODUÇÃO}

A ervilha (Pisum sativum L.), um dos alimentos mais produzidos no mundo, é pertencente a família Fabaceae, originaria no Oriente Médio, do Nordeste da Índia até o Afeganistão. No Brasil, a cultura adapta-se melhor no centro sul, em regiões serranas ou de planalto, com elevadas altitudes.

Uma das principais doenças que ocorrem na cultura é o oídio, causada pelo fungo biotrófico Erysiphe pisi DC. A doença apresenta grande importância econômica porque prejudica o desenvolvimento da planta, o fungo infecta as folhas, estípulas, hastes, gavinhas, vagens e sementes, ocasionando desde murcha até a morte, gerando perdas diretas ao produtor.

No Brasil Central, o clima seco, com baixa precipitação e umidade relativa, prevalente durante o período de cultivo, tem favorecido o desenvolvimento da doença, sendo registradas perdas de mais de 50\% (STADNIK \& RIVERA, 2001).

O controle do oídio tem sido realizado por meio de pulverizações com fungicidas inibidores da síntese de ergosterol, porém estes químicos não são registrados para a cultura e os fungicidas registrados, proporcionam, na maioria das vezes, um controle insatisfatório. $\mathrm{O}$ uso de cultivares resistentes deve ser pensado como uma alternativa viável, mais sustentável e de efetivo controle no manejo da doença. 
As primeiras fontes de resistência genética em ervilha ao oídio foram relatadas em populações peruanas por Harland (1948) e nas cultivares comerciais Stratagem e Mexique 4, originárias de uma população mexicana (PIERCE, 1948; COUSIN, 1965). No Brasil, a primeira fonte de resistência relatada, foi a cultivar Triofin, que apresentou um bom nível de resistência ao patógeno (GIORDANO \& REIFSCHNEIDER, 1984), porém, há relatos que essa resistência já foi superada (MARQUES, 1993).

Em 2005, foi lançada no Brasil a cultivar MK-10, a planta é de cor verde escura, crescimento semi-determinado com internódios curtos e apresenta alto nível de resistência ao oídio. A base genética da resistência de MK-10 não é relatada, determinar o modo de herança deste caráter é necessário, o que permite aos programas de melhoramento genético da ervilha incorporar essa resistência em materiais suscetíveis ao oídio, porém, com características agronômicas superiores.

Desta forma, o presente trabalho objetivou elucidar a herança da resistência ao oídio em MK-10 e caracterizar alguns aspectos histológicos da infecção de $E$. pisi nessa cultivar. 


\section{REVISÃO DE LITERATURA}

\subsection{Aspectos gerais da ervilha}

A ervilha (Pisum sativum L.), um dos alimentos mais produzidos no mundo, é pertencente a família Fabaceae, originaria no Oriente Médio, do Nordeste da Índia até o Afeganistão, tendo como origem secundária a Etiópia. É uma das plantas de domesticação mais antiga, sendo cultivada desde o período neolítico, em aldeias primitivas, por volta de 7000 a 6000 a.C. (FILGUEIRA, 2007; CUTOLO FILHO, 2000).

A Organização Mundial da Saúde tem incentivado o consumo de hortaliças, dentre elas, a ervilha. Essa leguminosa é altamente nutritiva, destacando-se em sua composição centesimal, elevados teores de proteína, vitaminas do complexo B, principalmente tiamina, riboflavina e niacina, além de minerais como cálcio, ferro, fósforo e potássio (PEREIRA, 1989). Possui ainda, luteína, $\beta$-caroteno e violaxantina (CARVALHO, 2007).

A participação do Brasil no mercado mundial de ervilhas ainda é pouca, variando a área cultivada e a produção ao longo dos anos. O CEAGESP-SP registrou no ano de 2008 um volume de comercialização de 1638 toneladas, volume $41 \%$ menor que o ano de 2007 (AGRIANUAL, 2009). A ervilha industrializada perde competitividade para o produto importado do Chile, que apresenta condições agroecológicas mais favoráveis para o cultivo da cultura (FILGUEIRA, 2007). 
No Brasil, o cultivo da hortaliça é realizado no inverno, entre março e maio, período em que milhões de hectares de terra não geram renda e sofrem degradação por erosão (RODRIGUES et al., 1998).

A cultura adapta-se melhor, no centro sul do país, em regiões serranas ou de planalto, com altitude superior a 700m (FILGUEIRA, 2007), sendo as temperaturas ótimas às compreendidas entre 12 e $18^{\circ} \mathrm{C}$, com máximas de 21 a $24^{\circ}$ e mínimas de $7^{\circ} \mathrm{C}$. Temperaturas consecutivas, superiores a $30^{\circ} \mathrm{C}$, resultam em decréscimo do rendimento, pois pode prejudicar a qualidade dos grãos, por favorecer a transformação dos açúcares em amido (REIS, 1989). Apesar de tolerar baixas temperaturas, a geada pode prejudicar as flores e a formação das vagens (GIORDANO \& REIFSCHNEIDER, 1984). Chuvas na época da colheita comprometem a qualidade dos grãos, ocasionando descoloração (FILGUEIRA, 2007). A umidade do ar, não afeta diretamente o rendimentos dos grãos, fotoperíodo longo e alta intensidade luminosa são favoráveis a cultura (REIS, 1989).

A ervilha é herbácea, sua raiz principal produz grande quantidade de raízes laterais. Suas inflorescências são do tipo racemo e surgem das axilas das folhas. O número de nós até o surgimento da primeira flor, normalmente é constante, sendo a primeira flor produzida do quinto ao décimo nó para cultivares precoces e do décimo terceiro ao décimo quinto para cultivares tardias. As sementes são globosas, podendo ser lisas ou rugosas, verde ou amarelas (GRITON, 1986).

De modo geral, as ervilhas são classificadas como ervilhas de grãos e ervilhas de vagens. As ervilhas de grãos, geralmente apresentam flores brancas, sementes lisas ou rugosas, verdes ou amarelas e suas vagens não são comestíveis. As de vagens apresentam baixos teores de fibras e podem ser consumidas na forma de vagens verdes, incluindo grãos os imaturos, estas, apresentam flores roxas ou brancas, e são de crescimento indeterminado (MARQUES, 1993; FILGUEIRA, 2000).

A ervilha é autógama, e a sua polinização ocorre $24 \mathrm{~h}$ antes da abertura da flor (COOPER, 1938). A germinação do tubo polínico leva de 8 a 12 horas e a fertilização de 24 a 28 horas após a polinização (GRITTON \& WIERZBICKA, 1975). O estigma pode ficar receptivo ao pólen de alguns dias antes da antese até um dia após o murchamento da flor. O pólen é viável desde o momento da deiscência das anteras (WARNOCK \& HAGEDORN, 1954). 
A cultura apresenta quatro estádios de desenvolvimento: estádio inicial, que compreende o período que vai do plantio até a planta atingir $10 \%$ do seu desenvolvimento vegetativo (com quatro a cinco folhas verdadeiras); estádio vegetativo, que é do estabelecimento inicial da cultura até inicio do florescimento; estádio de florescimento $e$ desenvolvimento de vagens, período entre o inicio do florescimento até o início da maturação e estádio de maturação, inicio da maturação até a colheita (DOORENBOS \& KASSAN, 1979)

Diversos autores relatam a necessidade de água nos diferentes estádios de desenvolvimento da cultura. FERREIRA (1991) avaliando a suscetibilidade da produção de grãos de ervilha à deficiência hídrica em três estádios fenológicos observou que um bom suprimento de água no estádio de florescimento e desenvolvimento de vagens, proporcionou um incremento na produção de grãos.

A época de colheita varia com o tipo de grão produzido, podendo ser a produção de grãos secos, para posterior reidratação, grãos verdes ou vagens comestíveis (FILGUEIRA, 2007). O tempo de colheita é determinado pela aparência das vagens. Após atingirem a maturidade, a qualidade e o rendimento são inversamente proporcionais. Quanto mais tardia é a colheita, menor é a proporção de ervilhas pequenas, aumentando o rendimento. Por outro lado, o conteúdo de amido e a rigidez das ervilhas aumentam, reduzindo a qualidade e o valor comercial. Os valores de textura, densidade específica, e sólidos insolúveis em álcool, aumentam com a maturação o que contribui negativamente com a qualidade do produto (CARVALHO, 2007).

Viroses, bactérias, nematóides e fungos prejudicam o bom desempenho da cultura. Um dos patógenos que merece maior atenção é o fungo Erysiphe pisi DC agente causal do oídio (KIMATI et al., 2005).

\subsection{O fungo Erysiphe pisi}

E. pisi é um ascosmicota da ordem Erysiphales, família Erysiphaceae. Na fase imperfeita corresponde a Oidium erysiphoides, ordem Moniliales, família Moniliaceae (KIMATI et al., 2005). Os fungos causadores dos oídios são biotróficos, obtendo nutrientes para seu crescimento lançando o haustório dentro das células epidérmicas. O micélio produz 
pequenos conidióforos que irão produzir cadeias de conídios retangulares, ovais ou arredondados, que serão carregados pelo vento, disseminando a doença (AGRIOS, 2005).

O inóculo primário pode ser constituído de conídios e micélios sobreviventes em gemas dormentes ou em folhas que permaneceram em estádio vegetativo através das estações; ou conídios provenientes de uma epidemia ocorrida em áreas próximas à da cultura (BUTT, 1978). Em regiões que se observa a ocorrência da fase perfeita, quando as condições ambientais ou nutricionais são desfavoráveis, o fungo pode produzir corpos de frutificação, os quais, quando maduros, rompem-se ou se decompõe, liberando os ascósporos, que também são um dos inóculos primários do fungo (AGRIOS, 2005).

Em condições favoráveis, esses esporos germinam, produzindo micélio superficial, conidióforos, nas extremidades dos quais serão formados os conídios que dão o aspecto pulverulento às folhas e que servirão de inóculo para infecções secundárias (KIMATI et al., 2005).

A maioria dos isolados de oídio não possuem ascomas, não sendo, portanto, conhecida sua forma perfeita. No Brasil, não existe nenhum relato da forma sexual do fungo. A formação desses ascomas está relacionada com o estado nutricional e a idade das folhas do hospedeiro, além da baixa temperatura e atmosfera seca (ALLARD, 1971; DIXON, 1978; YARWOOD, 1978).

Caracterizações moleculares e morfológicas têm mostrado que os corpos de frutificações dos Oídios representam um tipo especial de ascocarpo que não pode ser propriamente classificado nem como cleistótecio nem como peritécio (SAENZ et al., 1994).

O apressório é distinto e moderadamente lobado. Os conidióforos são delgados, medindo de 7 a $10 \mu \mathrm{m}$ de largura, seguida por uma segunda célula conidiófora, de 20 a $55 \mu \mathrm{m}$. A célula-pé diminui em largura da base $(7,2-8,5 \mu \mathrm{m})$ para o topo $(6,2-7 \mu \mathrm{m})$. Os conídios são ovóide-cilindricos ou elipsoidal-cilíndricos, hialinos, usualmente com 40 a $47 \mu \mathrm{m}$ de comprimento e 15 a $17 \mu \mathrm{m}$ de largura; são ausentes em corpos de fibrosina, sendo, também solitários. O tubo germinativo pode ser longo ou curto e nasce das extremidades do conídio (BOESEWINKEL, 1977; BOESEWINKEL, 1980; FALLOON et al., 1989).

A liberação de conídios dos conidióforos é de maneira passiva, sendo a umidade do ar e a velocidade do vento que controlam essa liberação (BUTT, 1978). A água da 
chuva ou de irrigação lava os esporos das folhas para o solo, reduzindo a severidade da doença. Tempo seco e formação de orvalho são favoráveis ao fungo (KIMATI, 2005). A temperatura ótima para germinação de vários conídios do oídio é de $21^{\circ} \mathrm{C}$ (SCHNATHORST, 1965) variando de 11 a $28^{\circ} \mathrm{C}$ para desenvolvimento da infecção (YARWOOD, 1957).

Diversos autores tem estudado a influencia do fotoperíodo na germinação dos conídios de Erysiphe spp., incluindo E. pisi. Acredita-se, que o fotoperíodo curto, influencia na germinação, no alongamento do tubo germinativo (AYRES, 1983; SINGH \& SINGH, 1981; YARWOOD, 1932) e afeta a formação do apressório da hifa e a formação das colônias (CARVER \& CARR, 1978; HIRATA, 1967).

Quanto à umidade, o fungo tem a habilidade de germinar e colonizar o hospedeiro em condições de deficiência de água, porém, durante a colonização, torna-se menos resistente a essa falta (HANNAI, 2001). De acordo Horsham (2008), a umidade ideal para o crescimento do fungo é de $70 \%$. Já Uncinula necator (Schw.), agente causal do oídio da videira, também pertencente a família Erysiphaceae, necessita de uma alta umidade relativa, entre 40 e 100\% na superfície das folhas para haver a formação de haustórios (ALVES \& ALMEIDA, 2009).

Condições de cultivo e de alta fertilidade favorecem níveis elevados de carboidratos na planta, fomentando o crescimento do hospedeiro e geralmente a severidade do oídio (COELHO et al., 2000).

\subsection{A doença}

Em ervilha, a doença apresenta grande importância econômica, prejudicando o desenvolvimento de vagens e afetando a qualidade dos grãos produzidos. As perdas na produção dependem do estádio de desenvolvimento da cultura e intensidade de infecção (HANNAI, 2001). A doença reduz a biomassa da planta, altura, número de nódulos, número de vagens e sementes por planta (GRITTON \& EBERT, 1975).

No Canadá, existem relatos onde a ocorrência da doença produziu perdas que vão de 25 a $50 \%$. Nos Estados Unidos, as perdas variam de 10 a $20 \%$, sendo também, a qualidade das sementes afetada (HORSHAM, 2008). No Brasil, reduções na 
produtividade de mais de $50 \%$ foram relatadas em cultivares suscetíveis com ausência de controle (STADNIK \& RIVERA, 2001).

A planta é mais suscetível ao fungo no estádio de maturação dos grãos. O fungo infecta as folhas, estípulas, hastes, gavinhas, vagens e sementes da ervilha, ocasionando desde murchamento até a morte da planta (DIXON, 1978). Os primeiros sintomas são pequenos, pontos difusos, na superfície adaxial das folhas mais velhas. Com o progresso da doença, as lesões são branco-pulverulentas e o tecido contaminado se torna purpúreo e ocorre a formação dos corpos de frutificação nas lesões maduras (HAGEDORN, 1989).

Algumas cultivares apresentam um arroxeamento foliar ou pequenas pontoações pretas nas folhas e vagens. Nas vagens, além desses sintomas pode haver uma paralisação no crescimento, acarretando uma queda prematura. Em vagens mais velhas, pode causar um desenvolvimento desigual da parte afetada e sadia. Quando a planta está severamente atacada, pode apresentar encarquilhamento nas folhas, paralisação no crescimento e pode secar prematuramente, de baixo para cima, (KIMATI, 2005). A infecção na semente ocorre quando a severidade da doença é elevada (HAGEDORN, 1989).

As plantas infectadas com oídio apresentam alterações em processos fisiológicos básicos como fotossíntese e respiração (STADNIK \& RIVERA, 2001). A taxa fotossintética diminui com o progresso da doença, mas alterações ocorrem antes mesmo que os sintomas cloróticos sejam visíveis. Existe uma perda progressiva de componentes dos fotossistemas e clorofila durante o curso de infecção, não havendo especificidade de qual componente será perdido (HOLLOWAY et al., 1992). Alguns autores afirmam que o decréscimo da fotossíntese é devido a redução da expressão dos genes que codificam componentes do aparato sintético, outros dizem que a fotossíntese aumenta em locais distantes dos locais da planta não infectados (HIGGINS et al., 1985; WALTERS \& AYRES, 1983).

O controle do oídio tem sido realizado por meio de pulverizações com fungicidas (KUROZAWA \& PAVAN, 1997; MCGRATH \& THOMAS, 1998; SALES JÚNIOR et al., 2002). No Brasil, os fungicidas registrados para controle do patógeno são os benzimidazóis, triazóis e inorgânicos, a base de enxofre (AGROFIT, 2009), porém o uso de fungicidas aumenta o risco de surgimento de novas raças (GUIMARÃES \& SANTOS, 1991). 


\subsection{Resistência a oídio em ervilha}

O uso de cultivares resistentes deve ser pensado como uma alternativa viável e de efetivo controle no manejo da doença (MCGRATH E THOMAS, 1998; REIS et al., 2002). Cultivares resistentes como Triofin, Luíza, Viçosa, Marina, Samba, Maria ou Kodama são indicadas para o controle (KIMATI, 2005), porém, SANTOS et. al. (1993) relatam que a resistência de Triofin, Luiza, Marina e Kodama, não é do tipo imune, pois algumas linhagens cultivadas em condições de ambiente protegido podem apresentar algum crescimento micelial do fungo, com pontuações necróticas no estádio inicial das lesões. Cultivares como Mikado, Kriter, Cobri, Flávia e Rag 1020 são muito prejudicadas pelo oídio em anos quentes e quando se utiliza irrigação por gotejamento (KIMATI, 2005).

Plantas resistentes a fungos produzem maiores níveis de enzimas líticas, inibidores proteináceos de enzimas e uma grande variedade de produtos naturais que podem funcionar como antibióticos na resistência. Inúmeras produzem $\beta$-(1,3)-glucanase e quitinases, as quais, juntas, lisam e dissolvem as paredes das células dos fungos não melanizados. O etileno é um dos sinalizadores que estimula síntese dessas enzimas, indicando que elas podem fazer parte da resistência a doenças (MATIELLO et.al. 1997). Pode ocorrer também maiores acúmulos de fitoalexinas e proteínas relacionadas a patogênese (PASCHOLATI \& LEITE, 1995). Quanto ao teor de açúcares, conteúdo protéico e de nitrogênio, geralmente cultivares resistentes possuem menores níveis destes compostos em relação às cultivares suscetíveis (PARASHAR \& SINDHAN, 1986).

Quando uma interação patógeno-hospedeiro resulta numa intensidade máxima da doença, elas são descritas como compatíveis, e as interações contrárias a essa, são ditas incompatíveis (AGRIOS, 2005). No modelo gene-a-gene de FLOR (1946) a expressão de incompatibilidade depende da presença de genes para resistência no hospedeiro e de genes correspondentes para avirulência no patógeno, sendo esse modelo aplicado à maioria dos sistemas de doenças de plantas.

A resistência do hospedeiro aos Oídios pode ser vista como a capacidade da planta em evitar ou atrasar a penetração e ou subseqüente desenvolvimento do fungo. O isolamento de genes de resistência e de avirulência é uma ferramenta extremamente 
útil na caracterização das interações bioquímicas e pode ajudar, e muito, a desvendar questões revolucionárias e de genética de populações de Oídio (STADNIK \& RIVERA, 2001).

As primeiras fontes de resistência genética em ervilha ao oídio foram relatadas por Harland (1948) em populações encontradas na cidade de Huancabamba, situada nos Andes, ao norte do Peru. Realizando cruzamentos e retrocruzamentos dessas populações locais com a variedade suscetível "First of All", o autor sugeriu que a resistência seria monogênica recessiva, conferida pelo gene er (er: Erysiphe resistance) que é ligado ao gene responsável pela produção de antocianina $(A)$ que confere cor a flor, e este estaria ligado a série $L$, genes que determinam o número de nós para o aparecimento da primeira flor. Sendo que a ordem dos genes no grupo 1 seria $L . . . A . . . E r$.

Pierce (1948) relatou alto nível de resistência ao oídio na variedade mexicana Stratagem. Realizando cruzamentos com as cultivares suscetíveis Glacier e Shasta, verificou-se em um total de 330 plantas na F2, que 243 plantas foram suscetíveis e 87 foram resistentes, ajustando-se na razão 3/4suscetível: 1/4resistente. Os resultados foram confirmados na F3, concluindo que a resistência da cultivar Stratagem seria dada por um gene recessivo.

Na França, Cousin (1965) encontrou diferentes níveis de infecção em cultivares de ervilha. Naquelas condições, a cultivar Stratagem foi ligeiramente infectada por E. pisi e a cultivar mexicana Mexique 4, permaneceu praticamente livre do oídio. Através do cruzamento Stratagem x Mexique 4 e ambas com algumas cultivares suscetíveis, o autor concluiu que a resistência é condicionada por um par de alelos recessivo e que Stratagem e Mexique 4 possuem o mesmo alelo.

Heringa et al. (1969) testou em diferentes condições, as cultivares SVP 950, Mexique 4, SVP 942, Stratagem, SVP 951 e SVP 952, consideradas resistentes em seus países de origem. Foi observado que o nível de infecção é influenciado pela temperatura e umidade, levando-o a enquadrar essas populações em três grupos resistência, de acordo o nível de ataque. Cruzando esses materiais com cultivares locais consideradas suscetíveis: Hylgro, Pauli e Rondo, o autor concluiu que a resistência é condicionada por dois genes (erl e er2) com interação entre eles. A presença de um deles ou de ambos na forma homozigota recessiva confere resistência ao patógeno. Sob esses aspectos, os autores propuseram a seguinte constituição genética para as diferentes fontes de resistência estudadas: SVP 950 e Mexique 4 
(erl erl er2 er2), SVP 942 e Stratagem (er1 erlEr2Er2), SVP 951 e SPV 952 (ErlEr1 er2er2) e as cultivares suscetíveis Hylgro, Pauli e Rondo (ErlEr1 Er2Er2).

Segundo Saxena et al. (1975) a resistência da ervilha ao oídio é conferida por um par de alelos recessivos concordando com os resultados obtidos por Harland (1948), Pierce (1948) e Heringa et al. (1969).

Kumar (1981) por meio do cruzamento de 14 linhagens suscetíveis de ervilha (B 5115, B 5243, B 5064, B 5806, PI 2106613, PI 280064, 46C, R 300, NF, 477, 245, Early december, Satha e Bonneville 31) com a linhagem resistente S-143 originária da Inglaterra, propôs que a resistência ao oídio é devido a um par de genes recessivos duplicados, que concorda com os resultados de Heringa et al. (1969) para algumas populações.

Tiwari et al. (1997a) realizando cruzamentos da progênie JI 1559 (Mexique 4) com a cultivar suscetível Radley, a resistente Highlight (erl) e o acesso JI 2480 (er2), confrontou os resultados de Heringa et al. (1969), mostrando que a Mexique 4 carrega somente o gene erl para resistência.

Diferentes fontes de resistência completa ou incompleta têm sido descritas para E. pisi, havendo discordância em qual grupo de ligação do mapa genético da ervilha este (s) gene (s) pertencem. Marx (1971) mostrou que a resistência da ervilha ao oídio (er) estaria ligada ao marcador morfológico "Gritty" (Gty), concluindo que o er estaria ligado geneticamente ao grupo 3, indo em confronto aos resultados de Harland (1948). Mais tarde, Marx (1986) reconsiderou sua designação, retirando o er e o Gty do grupo 3 e não os enquadrando em outro grupo. Posteriormente, Wolko \& Weeden (1990) colocaram o er e o Gty no grupo 6, resultado confrontado por Gupta et al. (1992) que enquadrou o er no grupo 5.

Timmerman et al. (1994) confirmou os resultados de Wolko e Weeden (1990) utilizando as cultivares "Slow" e "Almota", com fonte de resistência possivelmente originaria da cultivar Stratagem ou PI 185183. Além disso, os autores sugerem a resistência dessas cultivares é conferida pelo par de alelos erlerl, no entanto, não descartam a hipótese da existência de outras fontes de resistência em outras cultivares.

Equipes de pesquisadores canadenses e americanos (Cereal Research Centre, Winninpeg, Morden Research Centre, Manitoba e Washington State University) determinaram por meio de marcadores moleculares, que a resistência ao oídio é condicionada 
pelos genes er1 e er2 (ODREJ et. al., 2003). Recentemente, Katoch et al. (2009) com o uso de marcadores de RAPD, indicaram que o gene er2 está ligado ao grupo de ligação 3.

No Brasil, em observações preliminares de campo, feitas no Planalto Central, foi relatada a primeira fonte de resistência ao oídio, a cultivar Triofin, de origem Holandesa, desenvolvida pela Royal Sluis, que apresentou um bom nível de resistência ao oídio (GIORDANO \& REIFSCHNEIDER, 1984). Porém, essa resistência vem sendo superada (SANTOS et al. 1993). Atualmente, vem sendo utilizada a cultivar MK-10 como fonte de resistência ao oídio no País, a planta é de cor verde escura, crescimento semi-determinado com internódios curtos e apresenta alto nível de resistência ao oídio, porém a base genética dessa resistência não é relatada.

Marques (1993), estudando a herança de resistência, realizou cruzamentos entre populações resistentes JI 1700, Stratagem e Triofin e a cultivar suscetível Mikado, após obter gerações F1, F2 e retrocruzamentos propôs que a resistência era devida a três genes recessivos, dos quais erl e er2 comportaram-se como genes duplicados e o alelo dominante de er3 para suscetibilidade, como epistático à ação dos genes erl e er2. Sendo a resistência condicionada pelos genótipos er1er1er2er2er3er3, Er1-er2er2er3er3 e erler1Er2er3er3.

Recentemente, um gene dominante que confere resistência ao oídio foi identificado em $P$. fulvum, sendo nomeado de Er3. P. fulvum é uma espécie selvagem, que possui características agronômicas indesejáveis, porém pode ser usada em cruzamentos com $P$. sativum para incorporação desse gene de resistência. Ao contrário do er2, o $\operatorname{Er} 3$ não é dependente da temperatura e confere resistência completa sob condições de campo (FONDEVILLA et al., 2007b). Em ambiente controlado, testes com dois isolados de E. pisi, originários de diferentes regiões geográficas vem demonstrando a eficiência desse gene no controle do oídio à campo (FONDEVILLA et al., $2007 \mathrm{a}, \mathrm{b}$ ).

Atualmente, marcadores moleculares para o gene Er3 vem sendo desenvolvidos para facilitar trabalhos de seleção de materiais resistentes a E. pisi (FONDEVILLA et al., 2008).

Até agora, o gene erl, presente em muitas linhagens de ervilha tem sido efetivo no controle, tanto em condições de campo quanto em ambiente protegido, porém isolados de E. pisi capazes de superar essa resistência sob condições experimentais tem sido 
relatados. O gene er2 tem provado ser menos duradouro, promovendo somente uma resistência foliar, podendo esta ser superada com uma elevada pressão de inóculo ou de acordo o ambiente de cultivo (TIWARI et al., 1997a; HERINGA et al., 1969). Essa instabilidade é devido a influência da temperatura e idade da folha na expressão do gene (FONDEVILLA et al., 2006). Ambos os genes são herdados independentemente e a combinação destes em uma cultivar, pode aumentar a durabilidade dessa resistência (TIWARI et al., 1997b).

Em meados da década de noventa, um extenso programa de melhoramento para conferir resistência ao oídio em ervilhas de sementes rugosas foi desenvolvido pelos EUA, Canadá e Índia. Diversas cultivares comerciais foram obtidas: Almoto, Aspen, Concord, Dacota, Gypsy, Knight, etc. Através do processo de hibridização, foram obtidas novas cultivares com resistência múltipla ao oídio, podridão de raiz e a viroses (WEEDEN \& PROVIDENTI, 1999). As primeiras cultivares comerciais de sementes lisas resistentes ao oídio foram registradas no Canadá: Tara, Tamor e tipo afila cv. Highlight. Subsequentemente, novas cultivares de sementes lisas, com resistência ao oídio e maior potencial produtivo foram lançadas: Melfort, Eclipse, Mozart, Montero, Minuet, etc. Nas condições européias, cultivares de sementes lisas com resistência ao oídio também foram lançadas na segunda metade da década de noventa (WARKENTIN et al., 2000).

A principal desvantagem da maioria das fontes de resistência ao oídio é o baixo potencial produtivo (HERINGA et al., 1969, TIWARI et al., 1997a, VAID \& TYAGI, 1997). Porém, mutações induzidas têm dado um papel importante no melhoramento genético da ervilha, onde mutagêneses químicas e físicas tem produzido genótipos com alta qualidade, alterando o florescimento, características de maturação e ao mesmo tempo conferindo resistência ao oídio (FILIPPETTI et. al., 2004). ODREJ et. al. (2003) em trabalho no sentindo de produzir linhagens de ervilha de sementes lisas, com alto potencial produtivo, qualidade e nível de resistência ao oídio, verificou que as progênies, AGT-01 (Gotik x Highlight x Consort-R), AGT-GH (Gotik x Highlight) tiveram efeitos positivos na produção de sementes, apresentando ao mesmo tempo resistência ao oídio.

Experiências gerais vêm mostrando que a resistência gênica ao oídio é efêmera, devido a evolução da virulência do patógeno. E. pisi é uma ameaça porque ele combina um infreqüente ciclo sexual com altas taxas de reprodução assexual e dispersão de esporos (FONDEVILLA et. al., 2007a). SCHROEDER \& POVVIDENTI (1965) relataram a 
quebra de resistência em algumas cultivares, entre elas Stratagem, considerada resistente, indicando a possível existência de raças específicas.

A dinâmica de resposta do patógeno à utilização de hospedeiros resistentes envolve mecanismos de variabilidade, tais como a recombinação sexual, a adaptação, a heterocariose e a mutação; os três últimos ocorrem independentemente da presença da forma perfeita. A heterocariose e a mutação são mecanismos de variabilidade comuns aos fungos imperfeitos (ALLARD, 1971; AGRIOS, 2005).

\subsection{Histologia da interação E. pisi - P. sativum}

Pela teoria evolucionista de Darwin, as plantas em sua evolução desenvolveram mecanismos diferentes de defesa contra agentes externos, competindo por luz e nutrientes, estando presentes nos mais diferentes ecossistemas (HARBORNE, 1993).

Embora os vegetais não apresentem nenhum sistema imunológico, eles são surpreendentemente resistentes a doenças provocadas por diversos agentes fitopatogênicos. Esses mecanismos de defesa podem ser originários de mutações herdadas, seleção natural e mudanças evolutivas (TAIZ \& ZEIGER, 2004).

Em termos gerais, as plantas se defendem contra os patógenos através de reações bioquímicas (mecanismos bioquímicos) nas células e tecidos, que produzem substâncias consideradas tóxicas ao patógeno; ou através de barreiras físicas (mecanismos estruturais), como cutícula, estômatos e lenticelas, células epidérmicas diferenciadas, agregações citoplasmáticas, halos, uma maior lignificação e a formação de papilas. Essas barreiras interferem com o progresso do fitopatógeno nos tecidos da planta e consequentemente na sua colonização (BERGAMIN FILHO et al., 1995; AGRIOS, 2005).

A lignina é uma dos maiores componentes das paredes celulares das plantas, sendo acumulada nas papilas e em torno dos halos, atuando como a primeira linha de defesa contra patógenos (BHUIYAN et al. 2009b).

Uma maior lignificação aumenta a resistência das paredes celulares a difusão de toxinas do patógeno para o hospedeiro e de nutrientes do hospedeiro para o patógeno (NICHOLSON \& HAMMERSCHMITT, 1992), aumenta a resistência a degradação das enzimas produzidas pelo fungo (BERGAMIN FILHO et al. 1995) e torna a parede celular 
do hospedeiro mais resistente às forças aplicadas pelo apressório na tentativa da penetração (BECHINGER et al., 1999).

As papilas são caracterizadas pela deposição de material heterogêneo entre a membrana plasmática e a parede celular no sítio de infecção, sob a hifa peg de penetração, atuando como uma barreira contra penetração e troca de metabólitos entre o hospedeiro e o patógeno (BERGAMIN FILHO et al. 1995). Análises histológicas e químicas vêm demonstrando a complexidade das papilas, as quais contêm calose, proteínas, vários compostos fenólicos e inorgânicos, como opala sílica e espécies reativas de oxigênio (ZEYEN et al. 2002).

Quando um patógeno supera essas primeiras linhas de defesa existentes no hospedeiro, há uma reorganização metabólica na planta visando conter o mecanismo invasor no sítio de infecção. Essa reorganização é desencadeada por proteínas codificadas por genes de resistência que reconhecem as proteínas de avirulência produzidas pelo patógeno, constituindo uma interação incompatível (AGRIOS, 2005).

Após esse reconhecimento, uma complexa rede de sinais mediada por moléculas sinalizadoras são formadas, dentre elas a rota do acido salicílico, que atua na resposta de defesa no local da infecção (RYALS et al., 1996). Este processo tem inicio pela alteração do fluxo de íons através da membrana plasmática, seguido pelo acúmulo de espécies reativas de oxigênio, como superóxido $\left(\mathrm{O}_{2}^{-}\right)$e peróxido de hidrogênio $\left(\mathrm{H}_{2} \mathrm{O}_{2}\right)$ que interagem com o óxido nítrico, causando a reação de hipersensibilidade (MCDOWELL \& DANGL, 2000).

A ocorrência da resposta de hipersensibilidade é comumente observada em interações envolvendo patógenos biotróficos (HAMMOND-KOSACK \& JONES, 2000) e parece ser um mecanismo freqüente para resistência do tipo monogênica a oídio em diversas espécies de plantas (COHEN et al., 1990).

A histologia da interação patógeno-hospedeiro, permite estudar o processo de infecção, esclarecendo os eventos pré-penetração, penetração e colonização nos tecidos do hospedeiro, além de desvendar possíveis mecanismos estruturais de resistência (BENTES \& MATSUOKA, 2005). 
Para o patossistema E. pisi - P. sativum há um razoável número de estudos macroscópicos da reação de cultivares de ervilha resistentes (portadoras dos genes erl e er2) e suscetíveis ao oídio, porém, a nível histológico a literatura é escassa.

Fondevilla at al. (2006) realizaram o primeiro estudo a esse nível, observando que a penetração de E. pisi em populações de ervilha carregando o gene erl foi prevenida através de modificações nas células epidérmicas, havendo a formação de poucos haustórios e colônias. E em populações carregando o gene er2 que a resistência é póspenetração, com a morte celular, complementada com a maturação das folhas, que reduziu a penetração do fungo.

O patossistema oídio (Blumeria graminis f. sp. hordei) - cevada é o caso mais bem estudado da interação patógeno hospedeiro, tanto a nível histológico como molecular (JØRGENSEN, 1992). A nível histológico foi observado que a resistência da cevada a B. graminis f. sp. hordei é devido a uma resposta de hipersensibilidade e a parede celular epidérmica, que impede a penetração fúngica. Essa resistência da parede celular, é devido a falta de uma proteína selvagem $M l o(60 \mathrm{kDa})$ que desregula a morte celular da folha (FREIALDEHOVEN et al., 1994, BÜSHAGES et al., 1997).

Mutantes de Arabdopisis thaliana resistentes ao oídio (E. cruciferarum e E. cichoracearum) tem sido identificados, no mutante $p m r$ com imunidade induzida, o fungo penetra a parede celular, mas não consegue se desenvolver. Acredita-se que essa resistência pós penetração é devido ao aumento na expressão de uma proteína relacionada à patogênese, a PR-1 (FRYE \& INNES, 1998; SCHULZE-LEFERT \& VOLGEL, 2000). 


\section{MATERIAL E MÉTODOS}

\subsection{Localização Experimental}

Os experimentos foram conduzidos em ambiente protegido, na Fazenda Experimental da FCA-UNESP no município de São Manuel-SP de maio a dezembro de 2009 (Figura 1.).

O local apresenta altitude de $740 \mathrm{~m}$, latitude de $22^{\circ} 46^{\prime} \mathrm{Sul}$, Longitude 48³4'a Oeste do meridiano de Greenwich. O clima é subtropical úmido, com estiagens no período de inverno. A precipitação média anual é de $1.534 \mathrm{~mm}$ e o solo classificado como Argissolo Vermelho Amarelo Distrófico (Utissol), e foi corrigido de acordo com a análise química coletada antes da instalação do experimento.

As médias de temperatura, umidade relativa do ar e radiação dentro do ambiente de cultivo foram respectivamente: $24,8{ }^{\circ} \mathrm{C}, 46,8 \% \mathrm{UR}$ e $425,6 \mu \mathrm{mol} \mathrm{m} \mathrm{s}^{-1}$. 


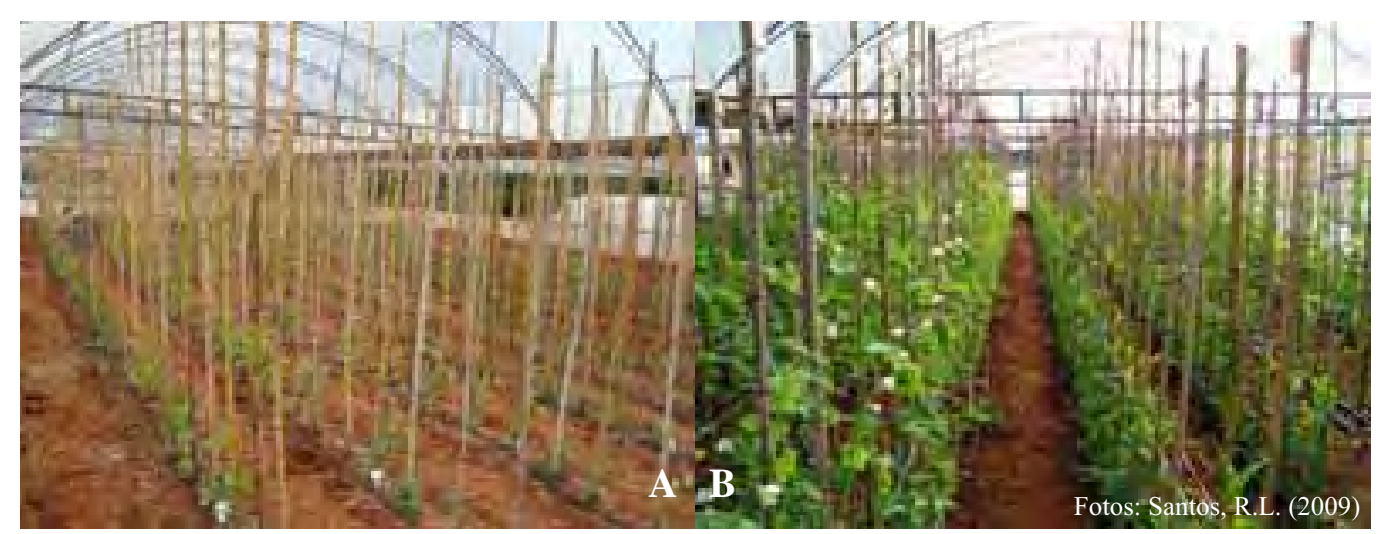

Figura 1. Vista geral do experimento em São Manoel-SP. A: Plantas de ervilha em estádio vegetativo, quinze dias após o transplante; B: Plantas de ervilha em floração e início da produção de vagens.

\subsection{Estudo da herança da resistência ao Erysiphe pisi}

Para os cruzamentos foram utilizadas as populações de ervilha: 08-02, que é uma linhagem avançada, originária do cruzamento entre Triofin e Torta de Flor Roxa, visando incorporar resistência poligênica ao oídio, obtida pelo professor Dr. Norberto da Silva no setor de Agricultura, área de Melhoramento Vegetal da Faculdade de Ciências Agronômicas, FCA-UNESP, Campus de Botucatu. A № 40, que é uma ervilha de porte determinado, destinada ao consumo de grãos frescos, suscetível ao oídio, comercializada por diversas empresas. E a cultivar MK-10, lançada em 2005 pela Sakata Seed Sudamerica, apresentando plantas de cor verde escura, crescimento semi-determinado com internódios curtos e alto nível de resistência ao oídio, porém a base genética dessa resistência não é relatada.

O período experimental foi dividido em duas fases. Na primeira, de maio a agosto de 2009, foram avaliadas as gerações F1 e F2, provenientes dos cruzamentos entre as cultivares de ervilha № 40 x MK-10 e 08-02 x MK-10 ambas constituindo a combinação suscetível x resistente. Avaliaram-se ainda os parentais MK-10, 08-02, № 40; as testemunhas: Triofin e Torta de Flor Roxa como padrão de resistência e suscetibilidade respectivamente; e uma população da cultivar Snap, para realização dos retrocruzamentos 
(devido à indisponibilidade de sementes da $\mathrm{N}^{\circ} 40$, utilizou-se Snap como padrão para suscetibilidade).

Para confirmar o modo de herança proposto na geração F2 conduziuse a segunda fase experimental, de setembro a dezembro de 2009. Foram avaliadas progênies F3 de plantas suscetíveis e resistentes e a geração F1 dos retrocruzamentos para os progenitores suscetíveis [(08-02 x MK-10) x 08-02] e [(08-02 x MK-10) x SNAP] e resistentes [(08-02 x MK-10) x MK-10]. Como testemunha, adotou-se a MK-10, Torta de Flor Roxa e Snap.

Os retrocruzamentos foram realizados em ambiente protegido, seguindo as técnicas descritas por GRITTON (1986). A emasculação foi realizada antes da polinização, para evitar que as flores fossem contaminadas com pólen estranho.

A epidemia foi aberta no ambiente de cultivo, sendo a principal fonte de inóculo a cultivar suscetível Torta de Flor Roxa. Para determinação da hipótese da herança, as plantas foram classificadas visualmente quanto à resistência ou suscetibilidade ao oídio, com base na presença ou ausência dos sinais do patógeno.

A primeira semeadura foi realizada em 16/05/2009 e a segunda em 23/09/2009. Foram utilizadas bandejas de poliestireno estendido (128 células) com substrato composto de $50 \%$ solo $+25 \%$ plantmax $^{\circledR}+25 \%$ esterco bovino e transplantadas em sulcos espaçados 0,8 metros entre si e 0,20 metros entre plantas nos sucos, sob condições de ambiente protegido. A adubação básica de plantio constou da aplicação de 50 g.m ${ }^{-1}$ do formulado 8-28-16.

\subsubsection{Condução experimental}

O delineamento experimental foi inteiramente casualizado sendo cada planta considerada uma repetição.

Foram avaliadas 18 plantas para a geração F1, 110 para o cruzamento 08-02 x MK-10 e 126 para o № 40 x MK-10 na geração F2. No cruzamento 08-02 x MK-10, a cada onze plantas, foi intercalada uma planta de MK-10 como padrão de resistência, uma de 08-02 e outra de Torta de Flor Roxa, com padrões suscetibilidade e fonte de inóculo. Para o cruzamento № 40 x MK-10, foi intercalada uma planta de № 40 e uma de Torta de Flor Roxa. 
Para o teste de progênies F3, foram selecionadas na geração F2, oito plantas resistentes e oito suscetíveis ao oídio do cruzamento № 40 x MK-10 e duas plantas resistentes e seis suscetíveis do cruzamento 08-02 x MK-10. Em ambos os casos, semearam-se 16 sementes por planta, totalizando 128 plantas resistentes e 128 suscetíveis do cruzamento № 40 x MK-10 e 32 resistentes e 96 suscetíveis do cruzamento 08-02 x MK-10.

Para os retrocruzamentos, foram avaliados vinte e seis indivíduos do retrocruzamento [(08-02 x MK-10) x MK-10], dezessete para o [(08-02 x MK-10) x 08-02] e trinta e quatro para o [(08-02 x MK-10) x SNAP].

No teste de progênies F3 e para os retrocruzamentos, a cada 16 plantas, foi intercalada uma planta de MK-10, uma de Snap e uma de Torta de Flor Roxa.

\subsection{Análises histológicas}

Os estudos histológicos foram conduzidos nas dependências do Departamento de Produção Vegetal da Faculdade de Ciências Agronômicas, UNESP, Campus de Botucatu: Setor da Defesa Fitossanitária.

$\mathrm{Na}$ primeira fase do período experimental, quando o patógeno estava distribuído uniformemente no ambiente de cultivo, foram coletados ao acaso, cinco folíolos de cinco plantas resistentes e cinco suscetíveis ao oídio por população.

De cada folíolo coletado, foi retirado um disco foliar de $20 \mathrm{~mm}$ de diâmetro. Os discos foliares foram colocados em placas de Petri e imediatamente transferidos para um câmara B.O.D permanecendo por $48 \mathrm{~h}$, à uma temperatura de $20 \pm 1^{\circ} \mathrm{C}$ com fotoperíodo de 12h, começando pelo escuro (RUBIALES E CARVER, 2000). O delineamento experimental adotado foi o inteiramente casualizado, constituindo cinco repetições por tratamento e um disco por repetição,

Para caracterizar os aspectos histológicos da infecção frente as populações resistentes e suscetíveis de ervilha, adotou-se a metodologia proposta por FONDEVILLA et al. (2006):

Após o período na B.O.D, os discos foliares foram colocados com a face abaxial para cima, em placas de Petri contendo papel filtro umedecido com ácido acético glacial e etanol, na proporção 1:3, para fixação das estruturas fúngicas. Quando os folíolos 
apresentaram-se descorados, foram transferidos para papel filtro umedecido com água para amolecer os tecidos, permanecendo por $2 \mathrm{~h}$. Em seguida, os discos foliares foram transferidos para papel filtro umedecido com lactoglicerol na proporção 1:1:1 (ácido lático:glicerol:água), para clareamento dos tecidos, permanecendo por $2 \mathrm{~h}$.

Para visualização ao microscópio com aumento de $200 \mathrm{X}$, os discos foliares foram corados em uma solução de $0,2 \%$ de azul de metil em 95\% de etanol (CARVER et al. 2001) e avaliados para os seguintes parâmetros:

- Porcentagem de germinação de conídios por disco foliar.

- Porcentagem de conídios germinados que formaram apressório.

- Porcentagem de conídios germinados com apressório que estabeleceram uma colônia (\% de colonização)

Após essa avaliação, foram escolhidas 20 colônias ao acaso por disco foliar e contado o número de haustórios por colônia. Para tal, foi necessário imergir os discos foliares em solução de azul de tripan (0,05\%) em lactofenol e etanol (1:2) por $1 \mathrm{~h}$ a $60^{\circ} \mathrm{C}$. Após esse período foi observado em $400 \mathrm{X}$ em microscópio interferencial de contraste (DIC).

\subsection{Análises Estatísticas}

No estudo da herança, as proporções fenotípicas observadas nas gerações F2, F3 e no retrocruzamento para progenitor resistente, obtidas pela avaliação da reação das plantas ao oídio, foram comparadas com as proporções fenotípicas esperadas, de acordo com os genótipos propostos para os progenitores, por meio do teste do Qui-quadrado $\left(\chi^{2}\right)$, conforme descrito por STRICKBERGER (1976).

Para os dados obtidos nas avaliações histológicas, foi realizada a análise de variância e as médias submetidas ao Tukey a 5\% de probabilidade com o programa estatístico SISVAR (FERREIRA, 2000). 


\section{RESULTADOS E DISCUSSÃO}

\subsection{Estudo da herança de resistência}

$\mathrm{Na}$ primeira fase do experimento, aproximadamente aos 60 dias após o plantio, iniciou a epidemia do oídio, época na qual a maioria das populações estavam em estádio de florescimento, algumas iniciando a produção de vagens. Por volta dos 80 dias, todas as plantas foram classificadas quanto à resistência ou suscetibilidade ao oídio.

Na geração F1, resultante do cruzamento entre progenitores suscetível e resistente, observou-se que as plantas foram completamente suscetíveis ao oídio. Para a geração F2, todas as plantas foram qualitativamente classificadas em resistentes ou suscetíveis a doença (Tabela 1).

Do cruzamento 08-02 x MK-10 obteve-se de um total de 110 plantas, 77 suscetíveis e 33 resistentes, ajustando-se na razão 3/4 suscetíveis: 1/4 resistente. O cruzamento № 40 x MK-10 apresentou o mesmo padrão de segregação, de 126 plantas, 97 segregaram para suscetibilidade e 29 para resistência (3/4 suscetíveis: 1/4 resistente). Para os parentais, não houve segregação para resistência e ou suscetibilidade. 
Tabela 1. Segregação para resistência ao oídio em ervilha da geração F2. São Manuel, SP -2009 .

\section{Segregação Observada}

\begin{tabular}{|c|c|c|c|c|}
\hline População & Geraçãa & Suscetível & Resistente & $\begin{array}{c}X^{2}(3 / 4: 1 / 4) \\
P=0,05\end{array}$ \\
\hline $08-02 \times$ MK-10 & $\mathrm{F} 1$ & 18 & - & - \\
\hline 08-02 x MK-10 & $\mathrm{F} 2$ & 77 & 33 & $1,46^{\mathrm{n} . \mathrm{s}}$ \\
\hline № $40 \times$ MK-10 & $\mathrm{F} 2$ & 97 & 29 & $0,25^{\mathrm{n} . \mathrm{s}}$ \\
\hline 08-02 & Parental & 23 & - & - \\
\hline № 40 & Parental & 25 & - & - \\
\hline MK-10 & Parental & - & 15 & - \\
\hline
\end{tabular}

n.s: não significativo a 5\% de probabilidade

Razões de segregação semelhantes foram obtidas por Saxena et al. (1975) avaliando o comportamento de populações na geração F2, originárias do cruzamento entre plantas resistentes e suscetíveis, por dois anos consecutivos, obtendo uma F1 totalmente suscetível e uma F2 segregando na razão 3/4 suscetíveis: 1/4 resistente, concluindo que a herança da resistência da ervilha ao oídio é monogênica recessiva.

Tiwari et al. (1997a) nos cruzamentos entre as cultivares resistentes Highlight, originária da Suécia, AC Tamor e Tara, originárias Canadá com a cultivar suscetível Radley originária da Inglaterra, obtiveram uma geração F1 totalmente suscetível e uma geração F2 segregando na razão 3/4 suscetíveis: 1/4 resistente, sugerindo que a base genética da resistência ao oídio dos genótipos utilizados é monogênica recessiva.

Vaid \& Tyagi (1997) realizando cruzamentos de nove cultivares resistentes (Wisconsin-7104, HPPC-63, HPPC-95, DPP-26, DPP-54, S-143, Mexique 4, SVP959 e P-6588) com a cultivar suscetível Lincoln, frente a ação de cinco isolados de E. pisi, 
encontraram uma geração F1 completamente suscetível e uma geração F2 segregando em 3/4 suscetíveis: 1/4 resistente, sugerindo que a resistência dos genótipos avaliados é conferida por um alelo gene recessivo.

Sharma (2003) realizou cruzamentos das cultivares resistentes Mexique 4, Tara, DMR 11 e S-143 com as suscetíveis Type 163 e Pusa 10, obtendo uma geração F1 totalmente suscetível e uma geração F2 segregando na razão de 3/4 suscetíveis para 1/4 resistente, concluindo que a resistência da ervilha ao oídio é controlada por um alelo recessivo.

Liu et al.(2003) cruzaram 13 linhagens de ervilha resistentes ao oídio de um programa de melhoramento australiano, com oito cultivares suscetíveis, todas originárias de diferentes regiões geográficas. Foi observada uma geração F1 totalmente suscetível e uma geração F2 com segregação ajustando-se na razão 3/4 suscetíveis: 1/4 resistente, concluindo que a resistência ao oídio de todas as progênies utilizadas é conferida por um gene recessivo.

Os resultados da geração $\mathrm{F} 1$, resultante do cruzamento entre progenitores suscetível e resistente e as segregações observadas na geração F2 do presente trabalho, estão de acordo com os resultados dos trabalhos citados, levantando a hipótese que a resistência ao oídio da cultivar MK-10 é monogênica recessiva. Os dados apresentados na tabela 1 não foram significativos a 5\% de probabilidade pelo teste do Qui-quadrado, apoiando a hipótese que a resistência da cultivar MK-10 é monogênica recessiva.

Por volta dos 45 dias após a instalação do experimento, deu-se inicio a epidemia do oídio na segunda fase experimental. Aos 70 dias, as plantas obtidas nos retrocuzamentos e as progênies F3 foram classificadas em resistentes ou suscetíveis ao oídio.

Para o retrocruzamento [(08-02 x MK-10) x MK-10], ocorreu segregação conforme o esperado para um retrocruzamento [(suscetível $\mathrm{x}$ resistente) $\mathrm{x}$ resistente] de uma herança monogênica recessiva. De um total de 26 plantas, 12 foram resistentes e 14 suscetíveis, seguindo a razão 1 suscetível :1 resistente (Tabela 2). Esses resultados estão de acordo aos de Sharma (2003) que realizou 11 retrocruzamentos [(suscetível x resistente) $x$ resistente], obtendo o mesmo padrão de segregação observado (1 suscetível: 1 resistente). 
Não foi observado padrão de segregação para as plantas avaliadas dos retrocuzamentos [(suscetível x resistente) x suscetível]. Para o retrocruzamento [(08-02 x MK10) $\mathrm{x}$ 08-02], todas as 17 plantas avaliadas foram suscetíveis e para o [(08-02 x MK-10) $\mathrm{x}$ SNAP], de um total de 34 plantas observadas, todas foram suscetíveis. Os resultados obtidos mostraram-se satisfatórios, ajustando-se na razão 0 resistente : 1 suscetível (Tabela 2). A mesma razão (0:1) foi observada por Marques (1993) realizando retrocruzamentos [(suscetível $\mathrm{x}$ resistente) $\mathrm{x}$ suscetível].

Os dados obtidos nos retrocruzamentos tanto para progenitores resistentes como suscetíveis, apóiam consistentemente a hipótese que a herança da resistência ao oídio da cultivar MK-10 é monogênica recessiva.

Tabela 2. Segregação para os retrocruzamentos com progenitores resistentes e suscetíveis. São Manuel, SP - 2009.

\section{Segregação Observada}

\begin{tabular}{|c|c|c|c|c|}
\hline População & Geração & Suscetível & Resistente & $\begin{array}{l}X^{2}(1: 1) \\
P=0,05\end{array}$ \\
\hline $\begin{array}{c}{[(08-02 \times \mathrm{MK}-10)} \\
\quad \mathrm{x} \mathrm{MK}-10]\end{array}$ & $\mathrm{F} 1$ & 12 & 14 & $0,01^{\text {n.s }}$ \\
\hline $\begin{array}{c}{[(08-02 \times \text { MK-10) }} \\
\text { x 08-02] }\end{array}$ & $\mathrm{F} 1$ & 17 & - & - \\
\hline $\begin{array}{c}{[(08-02 \times \mathrm{MK}-10)} \\
\mathrm{x} \text { SNAP }]\end{array}$ & $\mathrm{F} 1$ & 34 & - & - \\
\hline 08-02 & Parental & 23 & - & - \\
\hline Snap & Parental & 15 & - & - \\
\hline MK-10 & Parental & - & 15 & - \\
\hline
\end{tabular}

n.s: não significativo a $5 \%$ de probabilidade 
No teste de progênies F3, em ambos os cruzamentos, observa-se que não houve segregação para as plantas resistentes e os parentais. Algumas plantas consideradas suscetíveis na geração F2 segregaram de acordo o esperado para uma herança monogênica recessiva $3 / 4$ suscetíveis : $1 / 4$ resistente (Tabela 3 ).

Harland (1948) realizando cruzamentos de uma população de ervilhas peruanas, consideradas resistentes ao oídio, com a variedade suscetível "First of All" obteve os mesmos padrões de segregação nas gerações F1 e F2 observadas no presente trabalho (3/4 suscetíveis:1/4 resistente), confirmando na geração F3, que a herança da resistência ao oídio em cultivares peruanas de ervilha seria dada por um gene recessivo.

A mesma razão fenotípica de segregação na geração F3 foi encontrada nos trabalhos já citados: Tiwari et al. (1997a), Sharma (2003), Vaid \& Tyagi (1997) e Liu et al.(2003), os quais confirmaram através da geração F3, a hipótese levantada nas gerações F1 e F2, que a herança da resistência ao oídio dos genótipos utilizados nos respectivos trabalhos é monogênica recessiva.

A reação frente ao oídio de todas as plantas observadas na geração F3 estão de acordo as reações de resistência e ou suscetibilidade observadas na geração F2, confirmando que a resistência ao oídio da cultivar MK-10 é monogênica recessiva.

Os resultados obtidos na F1, F2, retrocuzamentos e testes de progênies F3 do presente trabalho, indicam que a base genética da resistência da cultivar MK-10, é monogênica recessiva, visto que, em todas as gerações, foi observada uma segregação de acordo a esse tipo de herança. Em todos os cruzamentos, os valores do Qui-quadrado foram não significativos a $5 \%$ de probabilidade, não rejeitando essa hipótese. 
Tabela 3. Segregação para resistência ao oídio em ervilha da geração F3. São Manuel, SP - 2009.

Segregação Observada

\begin{tabular}{|c|c|c|c|c|c|}
\hline População & Planta & $\begin{array}{c}\text { Reação } \\
\text { na F2 }\end{array}$ & Suscetível & Resistente & $\begin{array}{c}X^{2}(3 / 4: 1 / 4) \\
P=0,05\end{array}$ \\
\hline \multirow[t]{16}{*}{ № $40 \times$ MK-10 } & 199 & $\mathrm{~S}$ & 13 & 3 & $0,33^{\text {n.s }}$ \\
\hline & 224 & $\mathrm{~S}$ & 13 & 3 & $0,33^{\mathrm{n} . \mathrm{s}}$ \\
\hline & 231 & $\mathrm{~S}$ & 14 & 2 & $1,33^{\mathrm{n} . \mathrm{s}}$ \\
\hline & 235 & $\mathrm{~S}$ & 13 & 3 & $0,33^{\mathrm{n} . \mathrm{s}}$ \\
\hline & 253 & $\mathrm{~S}$ & 12 & 4 & $0,0^{\mathrm{n} . \mathrm{s}}$ \\
\hline & 295 & S & 16 & - & - \\
\hline & 308 & $\mathrm{~S}$ & 12 & 4 & $0,0^{\mathrm{n} . \mathrm{s}}$ \\
\hline & 369 & $\mathrm{~S}$ & 16 & - & - \\
\hline & 19 & $\mathrm{R}$ & - & 16 & - \\
\hline & 24 & $\mathrm{R}$ & - & 16 & - \\
\hline & 48 & $\mathrm{R}$ & - & 16 & - \\
\hline & 130 & $\mathrm{R}$ & - & 16 & - \\
\hline & 221 & $\mathrm{R}$ & - & 16 & - \\
\hline & 294 & $\mathrm{R}$ & - & 16 & - \\
\hline & 303 & $\mathrm{R}$ & - & 16 & - \\
\hline & 366 & $\mathrm{R}$ & - & 16 & - \\
\hline \multirow[t]{8}{*}{ 08-02 x MK-10 } & 90 & $\mathrm{~S}$ & 13 & 3 & $0,33^{\mathrm{n} \cdot \mathrm{s}}$ \\
\hline & 98 & $\mathrm{~S}$ & 12 & 4 & $0,0^{\mathrm{n} . \mathrm{s}}$ \\
\hline & 111 & $\mathrm{~S}$ & 14 & 2 & $1,33^{\mathrm{n} . \mathrm{s}}$ \\
\hline & 116 & $\mathrm{~S}$ & 13 & 3 & $0,33^{\mathrm{n} . \mathrm{s}}$ \\
\hline & 149 & S & 16 & - & - \\
\hline & 157 & S & 16 & - & - \\
\hline & 139 & $\mathrm{R}$ & - & 16 & - \\
\hline & 145 & $\mathrm{R}$ & - & 16 & - \\
\hline 08-02 & - & Parental & 23 & - & - \\
\hline № 40 & - & Parental & 25 & - & - \\
\hline MK-10 & - & Parental & - & 15 & - \\
\hline
\end{tabular}

n.s: não significativo a 5\% de probabilidade. S: suscetível, R: resistente 
Apesar de esclarecida a recessividade da resistência, os estudos da herança de resistência da ervilha ao oídio são altamente contraditórios, havendo discordância entre os autores quanto ao número de genes envolvidos controlando essa característica (TIWARI et al., 1997a). Harland (1948) demonstrou que a resistência seria monogênica recessiva; Heringa (1969) concluiu que a manifestação do caráter é devido a dois genes recessivos distintos; Beek (1985) e Gupta et al. (1995) sugeriram que a resistência é de herança poligênica; Kumar (1981) sugere que é dada por um par de genes recessivos duplicados.

Até então, são conhecidas três fontes de resistência: Mexique 4 er1Er2 (TIWARI et al. 1997a); Stratagem - er1Er2 e Svp952 -Erler2 (HERINGA et al., 1969).

As diferenças na interpretação do número de genes envolvidos na resistência da ervilha ao oídio podem ser devido à diversidade de genótipos que vem sendo estudados; a possível existência de raças de E. pisi; e a fatores ambientais que podem influenciar tanto na expressão do genes de resistência quanto no desenvolvimento do fungo (FONDEVILLA et al., 2008; KIMATTI et al., 2005; TIWARI et al., 1997a,b;).

A diversidade de genótipos estudados é um fator de grande influência para os resultados contraditórios dos diversos trabalhos. Não é assegurado que, apesar da mesma origem geográfica, alguns pesquisadores utilizaram em seus trabalhos as mesmas fontes de resistência que outros, podendo existir grande variabilidade nas fontes de resistência dentro de uma mesma região.

O Oídio é um patógeno com alguns isolados mais virulentos que outros (TIWARI et al., 1997b) sendo amplamente distribuído no mundo, havendo evidências da existência de raças fisiológicas (SCHOROEDER \& POVVIDENTI, 1965).

Tiwari et al. (1997b) estudaram a variação da patogenicidade de 31 isolados de E. pisi, coletados no Canadá e nos Estados Unidos, em 14 progênies de ervilha, realizando testes em nove regiões geográficas. Os autores observaram que cultivares como Radley, considerada suscetível no Canadá, foi resistente no Nepal; JI 2480 foi resistente na Califórnia e Manitoba, porém suscetível em Nova York, sugerindo assim, a existência de uma grande variação da patogenicidade dos isolados. 
A possível seleção de novas raças se deve principalmente a base genética da resistência ao oídio da maioria da cultivares de ervilha. Essa resistência é do tipo monogênica, condicionada por um ou poucos genes, gerando uma pressão de seleção sobre o patógeno. Essa pressão neutraliza a ação dos genes, principalmente devido a seus mecanismos de variabilidade, como mutações e recombinações, tornando esse tipo de resistência pouco durável (MATIELLO et al., 1997). Porém, esse tipo de resistência é preferida pelos melhoristas, pois é facilmente incorporada dentro de materiais suscetíveis através de simples retrocruzamentos (FONDEVILLA et al., 2008).

Diferentes reações para resistência ou suscetibilidade de genótipos específicos em diferentes locais, também pode ser devido ao nível de inóculo presente e das condições ambientais, como luminosidade, umidade e temperatura (TIWARI et al. 1997b).

No geral, elevadas temperaturas, bloqueiam a formação de compostos fenólicos pela planta e o desenvolvimento de mecanismos estruturais que dificultam a colonização do tecido vegetal pelo patógeno. Heringa et al. (1969) observou que há influência da temperatura e umidade sob a severidade do oídio em genótipos de ervilha resistentes e suscetíveis, dividindo as populações utilizadas em seu trabalho em grupos de resistência de acordo o nível de ataque nas três condições de cultivo adotadas, campo e ambiente protegido a $12^{\circ}$ e $20^{\circ} \mathrm{C}$. Fondevilla et al. (2006) cita que populações de ervilha possuindo o gene er2, vêm demonstrando maior resistência à oídio em temperaturas acima de $25^{\circ} \mathrm{C}$.

O uso de cultivares resistentes tem sido uma das principais medidas de controle para o oídio em ervilha, porém a descoberta de novas fontes de resistência se faz necessária, principalmente fontes com resistência quantitativa ou poligênica, que é um tipo de resistência mais durável. Nesse tipo de resistência, ocorre a ausência da interação diferencial entre o patógeno e o hospedeiro, ou seja, o hospedeiro é resistente a todas as raças do patógeno. 


\subsection{Análises histológicas}

Os resultados do presente trabalho demonstraram uma mesma eficiência na porcentagem de conídios germinados e porcentagem de conídios germinados que formaram apressório entre as populações da geração F2 consideradas resistentes e suscetíveis ao oídio, não havendo diferença estatística entre os genótipos de ervilha utilizados (tabela 4).

Dados semelhantes foram obtidos por Resser \& Hagedorn (1983), concluindo que a germinação de conídios e a formação de apressórios não são suficientes para caracterizar a infecção de populações de ervilha resistentes e suscetíveis ao oídio. Marques (1993) realizou a contagem do número de conídios nas populações de ervilha JI 1700, Triofin, Stratagem, consideradas resistentes ao oídio e nas suscetíveis Mikado e Flávia, observando que não houve diferença na germinação dos conídios entre essas populações.

Em progênies de ervilha, originárias do cruzamento Lathyrus odoratus x Lathyrus belinensis L. uma mesma razão de germinação entre acessos resistentes e suscetíveis ao oídio foi encontrada, porém, após a germinação, o tubo germinativo entrou em colapso devido a uma morte celular (POULTER et al., 2003).

Fondevilla et al. (2006), verificaram que não houve diferença na porcentagem de conídios germinados e porcentagem de conídios germinados que formaram apressórios entre populações resistentes e suscetíveis ao oídio em ervilha. Fernàndez-Aparicio et al. (2009) caracterizando os mecanismos histológicos de resistência em beterraba (Beta vulgaris) ao oídio (Erysiphe betae), também não encontraram diferenças na germinação entre os genótipos resistentes e suscetíveis.

Resultados contrários foram observados por Rubiales \& Carver (2000) que verificaram uma menor porcentagem de germinação de conídios em populações resistentes de 15 acessos de cevada (Hordeum chilense) à Blumeria graminis DC Speer f.sp. hordei, Blumeria graminis f.sp. tritici e Blumeria graminis f.sp. avenae, atribuindo esse resultado a uma diferença da viabilidade dos inóculos testados. Johnson et al. (1981) demonstraram que a germinação dos esporos de B. graminis f.sp. tritici foi uniformemente alta em trigo, aveia e centeio, sendo menor em gramíneas e outras monocotiledôneas não hospedeiras, indicando que estas apresentam algum fator inibitório para germinação. 
Tabela 4. Valores médios dos estádios de desenvolvimento de E. pisi em populações F2 resistentes e suscetíveis ao oídio em ervilha. FCA-UNESP, Botucatu - SP, 2009.

\begin{tabular}{|c|c|c|c|c|c|}
\hline Populações & $\begin{array}{l}\text { Reação } \\
\text { ao oídio }\end{array}$ & $\begin{array}{c}\text { Conídios } \\
\text { germinados }(\%)\end{array}$ & $\begin{array}{c}\text { Conídios que } \\
\text { formaram } \\
\text { apressório (\%) }\end{array}$ & $\begin{array}{c}\text { Colonização } \\
(\%)\end{array}$ & $\begin{array}{l}\mathbf{N}^{\circ} \text { haustórios } \\
\text { por colônia }\end{array}$ \\
\hline Torta de F. Roxa & $\mathrm{S}$ & $88,4 \mathrm{a}$ & $77,0 \mathrm{a}$ & $91,2 \mathrm{c}$ & $2,8 \mathrm{~d}$ \\
\hline № 40 & $\mathrm{~S}$ & $85,6 \mathrm{a}$ & $82,2 \mathrm{a}$ & $84,2 \mathrm{c}$ & $2,0 \mathrm{bcd}$ \\
\hline Snap & $\mathrm{S}$ & $86,2 \mathrm{a}$ & $88,4 \mathrm{a}$ & $83,2 \mathrm{c}$ & $2,4 \mathrm{~cd}$ \\
\hline MK-10 & $\mathrm{R}$ & $90,2 \mathrm{a}$ & $90,2 \mathrm{a}$ & $1,8 \mathrm{a}$ & $0,4 \mathrm{a}$ \\
\hline Triofin & $\mathrm{R}^{*}$ & $91,0 \mathrm{a}$ & $92,6 \mathrm{a}$ & $89,4 \mathrm{c}$ & $1,8 \mathrm{bcd}$ \\
\hline 08-02 & $\mathrm{R}^{*}$ & $85,2 \mathrm{a}$ & $85,0 \mathrm{a}$ & $35,4 \mathrm{~b}$ & $1,2 \mathrm{abc}$ \\
\hline$(08-02 \times \mathrm{MK}-10-\mathrm{F} 2)$ & $\mathrm{S}$ & $87,4 \mathrm{a}$ & $93,0 \mathrm{a}$ & $88,0 \mathrm{c}$ & $2,0 \mathrm{bcd}$ \\
\hline$(08-02 \times \mathrm{MK}-10-\mathrm{F} 2)$ & $\mathrm{R}$ & 83,0 a & 90,8 a & $2,0 \mathrm{a}$ & $0,6 \mathrm{ab}$ \\
\hline (№ $40 \times$ MK-10 - F2) & $\mathrm{S}$ & $88,3 \mathrm{a}$ & $94,8 \mathrm{a}$ & $93,0 \mathrm{c}$ & $2,2 \mathrm{bcd}$ \\
\hline (№ $40 \times$ MK-10 - F2) & $\mathrm{R}$ & $86,4 \mathrm{a}$ & 93,8 a & $1,8 \mathrm{a}$ & $0,4 \mathrm{a}$ \\
\hline $\mathrm{CV}(\%)$ & - & 4,6 & 14,6 & 8,2 & 37,5 \\
\hline
\end{tabular}

* Resistência moderada ao oídio

Médias seguidas pela mesma letra na coluna, não diferem entre si pelo teste Tukey a 5\% de probabilidade R - Resistente; S - Suscetível

Fondevilla et al. (2007b) visando identificar novas fontes de resistência em espécies de Pisum spp. a E. pisi, observaram menores médias na porcentagem de germinação e na porcentagem de esporos germinados que formaram apressório em genótipos resistentes quando comparados com os suscetíveis ao oídio. Os autores sugeriram que um fator químico ou estrutural em comum as espécies resistentes de Pisum spp. é o responsável pela redução da porcentagem dos componentes de resistência. 
Uma baixa formação de apressórios em espécies de ferrugem em progênies resistentes de Hordeum chilense foi relatada por Rubiales e Nicks (1992). No material resistente, a baixa formação de apressórios foi devido a uma possível desorientação do tubo germinativo (causada por alguma modificação morfológica, composição da cutícula e gradiente de $\mathrm{pH}$ na folha) ou devido a não diferenciação da hifa em apressório, pelo não reconhecimento do estômato para posterior penetração.

Para Vilijanen-Rollinson et al., (1998) o genótipo de um hospedeiro pode afetar a germinação dos conídios em algumas interações patógeno-hospedeiro pela ausência de estímulos para germinação, presença de componentes que a inibem, estes ainda não são bem conhecidos, e características morfológicas que afetam a folha favorecendo ou não o processo. Já a formação apressorial pode ser influenciada por mudanças químicas e físicas nas células epidérmicas e na cutícula, ocasionadas por fatores ambientais e idade da planta (HOTO \& PASCHOLATI, 2000).

Como não foi observada diferença na porcentagem de germinação dos conídios e na formação apressorial entre as populações de ervilha resistentes e suscetíveis ao oídio do presente trabalho, acredita-se na ausência de fatores que influenciam esses processos. Esses resultados estão de acordo a NIKS \& RUBIALES, (2002) que têm concluído que a germinação conidial não é um fator importante que contribui na resistência das plantas a Erysiphe spp.

$\mathrm{Na}$ tabela 4 encontra-se ainda os dados referentes a porcentagem de conídios germinados com apressório que estabeleceram colônias (\% de colonização) e o número de haustórios por colônia.

As populações suscetíveis não diferiram entre si para a \% de colonização e o número de haustórios por colônia. Nota-se que a Torta de Flor Roxa apresentou as maiores médias para esses parâmetros; foi notável o alto nível de infecção dessa população também a campo (Figura 2). 


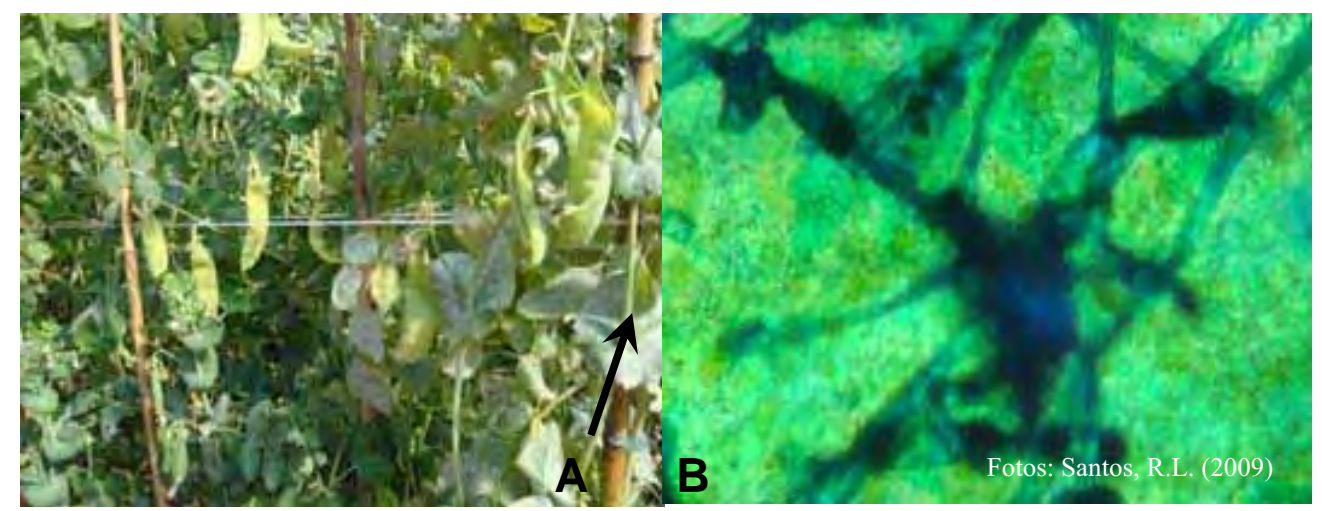

Figura 2. Torta de Flor Roxa infectada por E. pisi, FCA-UNESP, 2009. A: Planta infectada aos 90 dias, período de maturação de vagens. B: Colônia estabelecida nos folíolos.

A população de Triofin não diferiu das populações suscetíveis para a \% de colonização. Para o número de haustórios, houve semelhança estatística com a № 40, apresentando 1,8 e 2,0 haustórios/colônia respectivamente, sendo menor que a Torta de Flor Roxa e Snap.

Apesar de ser relatada como resistente por Giordano \& Reifschneider (1984) a reação fenotípica observada no presente trabalho na cultivar Triofin foi de um material suscetível, estando de acordo aos resultados obtidos por Marques (1993). A reação para a suscetibilidade de Triofin e os elevados valores observados em Torta de Flor Roxa pode ser devido à alta concentração do potencial de inóculo observada a campo, pois as condições ambientais estavam extremamente favoráveis ao desenvolvimento do patógeno.

Valores intermediários foram observados no parental 08-02, que apresentou 35,4\% de colonização e 1,2 haustórios/colônia. Isso sugere que 08-02 é moderadamente resistente ao oídio. Essa população é originária do cruzamento Triofin $\mathrm{x}$ Torta de Flor Roxa e a base genética da resistência de Triofin não é bem esclarecida (Comunicação pessoal ${ }^{*}$ ), existindo relatos que essa resistência não é do tipo imune, podendo haver crescimento micelial em condições de ambiente protegido (SANTOS et al. 1993)

Para as progênies dos cruzamentos 08-02 x MK-10 e N 40 x MK-10, que segregaram para suscetibilidade, $88 \%$ e $93 \%$ dos conídios germinados tiveram sucesso no

\footnotetext{
${ }^{*}$ Comunicação pessoal com o Prof. Dr. Norberto da Silva, Prof. Titular da FCA-UNESP, Campus de Botucatu SP, em dezembro de 2009.
} 
estabelecimento de colônias. O mesmo foi observado para o número de haustórios, que apresentou uma média de 2,0 e 2,2 haustórios/colônia respectivamente, não diferindo entre si e das populações suscetíveis.

Nas plantas que segregaram para resistência dos cruzamentos 08-02 x MK-10 e No40 x MK-10 e na cultivar resistente MK-10, observa-se que não houve sucesso na formação de colônias, apresentando uma média de $2 \%, 1,8 \%$ e 1,8 \% dos conídios germinados que estabeleceram colônias respectivamente.

Comportamento semelhante foi verificado para o número de haustórios, onde as progênies resistentes 08-02 x MK-10 e No40 x MK-10 e a cultivar MK-10 apresentaram uma média $0,6,0,4$ e 0,4 haustórios por colônia respectivamente, valores significativamente inferiores aos das demais populações.

Pela elevada produção de apressórios e baixa porcentagem de colonização, sugere-se que a resistência expressa pelas progênies resistentes e a cultivar MK-10 é devido a algum mecanismo de defesa estabelecido antes da penetração (resistência pré-penetração). Apesar de não ter sido identificado pela técnica utilizada, supõem-se que esse mecanismo é conferido por uma elevada lignificação e pela formação de aposições nas paredes celulares, as papilas.

Moerschbacher et al. (1990), mostraram o papel da lignificação na resistência contra fitopatógenos aplicando um inibidor da síntese de lignina em plantas de trigo. Nas plantas em que foi aplicado esse inibidor, os autores observaram um aumento da colonização por Puccinia graminis f. sp. tritici quando comparadas com as plantas que produziam lignina normalmente.

Um acúmulo de lignina tem sido responsável pela resistência do trigo a Fusarium graminearum (MOHAMMADI \& KAZEMI, 2002), do pepino a Pythium aphanidermatum (CHEN et al. 2000) ao míldio (Peronospora parasitica) e ao Colletotrichum lageniarum (MATSUMOTO \& ASADA, 1984). Em trigo, a lignificação das papilas é a primeira linha de defesa ao oídio, Blumeria graminis (BHUIYAN et al. 2009a).

Por meio das papilas e reforço da parede celular, a penetração de $B$. graminis f. sp. hordei em cevada vem sendo relatada, porém essa resistência é incompleta, pois uma grande proporção das tentativas de penetração tem sucesso, causando infecção 
(GJETTING, et al., 2004). A resistência do hospedeiro nesse patossistema é completada pela morte celular, havendo um acúmulo de $\mathrm{H}_{2} \mathrm{O}_{2}$ (HUCKELHOVEN et al., 1999).

A formação de papilas é responsável pela resistência ao oídio (Sphareotheca pannosa) nas espécies de roseira Rosa wichuraiana e R. laevigata, e quando o fungo supera essa barreira, a resistência é complementada por um colapso celular em $R$. wichuraiana e uma maior produção de fitoalexinas em $R$. laevigata (DEWITTE et al., 2007).

Anker \& Niks (2001) observaram que as papilas são as responsáveis pela resistência de três acessos de trigo diplóide (Triticum monococcum) a ferrugem Puccinia triticina.

Nas plantas resistentes e na cultivar MK-10, verificou-se uma morte celular localizada (reação de hipersensibilidade), quando a barreira possivelmente imposta pela lignificação e papilas foi superada (Figura 3), o que justifica o reduzido número de haustórios encontrados nessas populações.

Esses resultados estão de acordo aos de Fondevilla et al. (2006) que objetivaram investigar os mecanismos celulares responsáveis pela resistência ao oídio em populações de ervilha portadoras do alelo erl, verificando uma resistência a penetração de $E$. pisi através das células epidérmicas, o que reduziu a colonização, havendo a formação de poucos ou nenhum haustório por colônia, e quando estes eram formados, seu desenvolvimento era suprimido pela morte celular.

Essa morte celular localizada é relatada em outros patossistemas envolvendo oídio em que a resistência é conferida por alelos recessivos. No patossistema oídio-cevada, a hipersensibilidade é correlacionada com a resistência mediada pelo alelo Mla (ZEYEN et al., 1995). Em melão resistente quando inoculado com uma raça incompatível de Sphaerotheca fuliginea (raça 1) observa-se reação de hipersensibilidade, acumulação de calose e lignificação das células epidérmicas(COHEN, et al. 1990). 


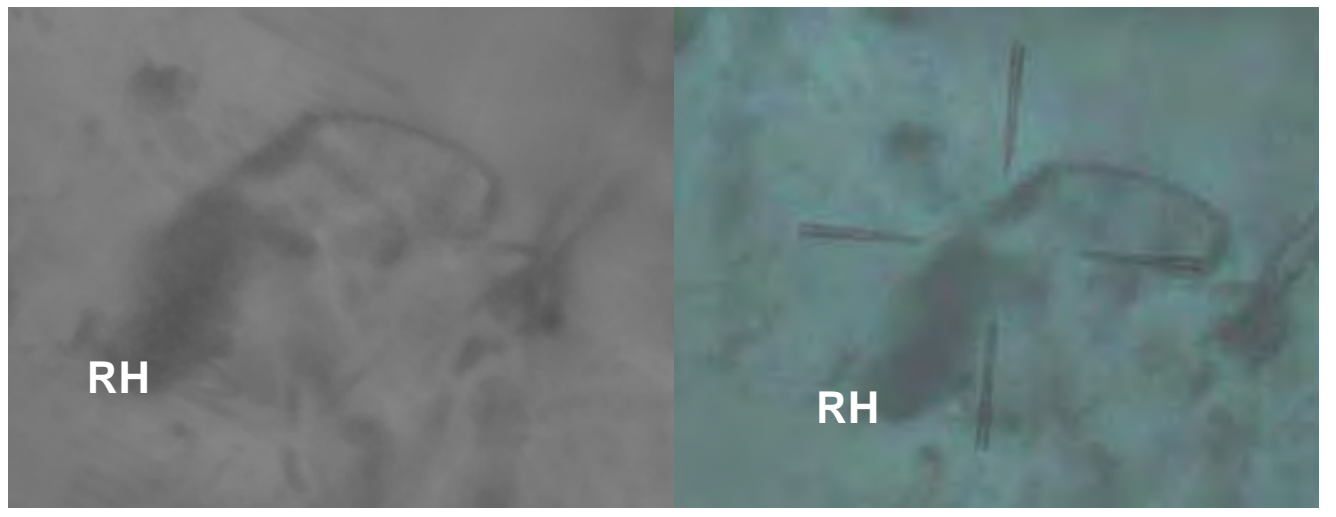

Figura 3 - Reação de hipersensibilidade $(\mathrm{RH})$ em conídios germinados em folíolos de ervilha, FCA-UNESP, 2009.

Em tomateiro, os genes dominantes $O l$ conferem resistência ao oídio (Oidium neolycopersici) por meio da reação de hipersensibilidade e o gene recessivo ol-2 por meio da formação de papilas (BAI, 2004).

Em espécies de carvalho (Quercus spp.) apresentando diferentes níveis de resistência ao oídio (Michosphaera alphitoides), não foi encontrada diferenças na formação apressorial, porém o desenvolvimento da infecção nas espécies mais resistentes foi devido a morte celular e a produção de papilas. Foram identificadas ainda dois tipos de papilas, lignificada ou não, as papilas com lignificação foi mais comum nas plantas mais resistentes (EDWARDS \& AYRES, 1981). Morte celular tem sido identificada em populações resistentes de Lactuca saligna L. ao míldio (Bremia lactucae) conferida pelos genes DM (LEBEDA \& REININK, 1994).

Os dados obtidos no estudo da herança permitiram concluir que a resistência de MK-10 ao oídio é monogênica recessiva. Embora a realização de testes de alelismo entre a cultivar MK-10 e cultivares com genótipos de resistência conhecidos permitem concluir asseguradamente qual o gene que confere resistência ao patógeno, no presente estudo a identificação do gene foi por meio de estudos histológicos.

As observações realizadas no presente estudo histológico estão de acordo as verificadas por Fondevilla et al. (2006). Assim, sugere-se que a resistência ao oídio 
da cultivar MK-10 é conferida possivelmente pelo par de alelos erlerl e que essa resistência é dada na fase de pré e pós-penetração.

A pré-penetração, atuando através da formação de papilas e ou lignificação; pós-penetração quando a primeira barreira de resistência é superada, havendo uma resposta de hipersensibilidade, assegurando a resistência dessa cultivar. 


\section{CONCLUSÃO}

Nas condições agroecológicas em que foi desenvolvimento o experimento conclui-se que a resistência ao oídio da cultivar MK-10 é conferida por um par de alelos recessivos, provavelmente o erlerl, que se expressa na fase de pré-penetração e se completa pela morte celular localizada (reação de hipersensibilidade) caso as barreiras primárias sejam superadas pelo patógeno. 


\section{REFERÊNCIAS}

AGRIANUAL 2008: anuário da agricultura brasileira. São Paulo: FNP, 2009. 495p.

AGRIOS, G. N. Plant pathology. 5th ed. London, UK: Elsevier Academic, 2005. 921 p.

ALLARD, R. W. Princípios do melhoramento genético das plantas. Rio de Janeiro: USAID, 1971.

ALVES, F.; ALMEIDA, F. Contributo para a discussão de estratégias de combate ao oídio da videira Uncinula necator (Schw.) Burr na Região Demarcada do Douro. Victoria: Associação para o Desenvolvimento da Viticultura Duriense, 2009. 9 p. Disponível em: <http://www.bayercropscience.pt/download/oidio_douro.pdf >. Acesso em: 30 abr. 2009.

ANKER, C. C.; NIKS, R. E. Prehaustorial resistance to the wheat leaf rust fungus, Puccinia triticina, in Triticum monococcum s.l. Euphytica, Wageningen, v. 117, p. 209-215, 2001.

AYRES, P. G. Conidial germination and germ tube growth of Erysiphe pisi in relation to visible light and its transmission through pea leaves. Transactions of the British Mycological Society, London, v. 81, p. 269-274, 1983.

BAI, Y. The genetic and mechanisms of resistance to tomato powdery mildew (Oidium neolycopersici) in Lycopersicon species. 2004. $103 \mathrm{f}$. Tese (Doctor in Biotechnology)Wageningen University, The Netherlands, 2004.

BECHINGER, C. et al. Optical measurements of invasive forces exerted by appressoria of a plant pathogenic fungus. Science, Washington, v. 285, p. 1896-1899, 1999.

BEEK, A. M. et al. Método de seleção para resistência parcial de ervilha (Pisum sativum L.) para oídio (Erysiphe pisi D.C.). Fitopatologia Brasileira, Brasília, DF, v. 10, n. 2, p. 288, 1985.

BENTES, J. L. S.; MATSUOKA, K. Histologia da interação Stemphylium solani e tomateiro. Fitopatologia Brasileira, Brasília, DF, v. 30, p. 224- 231, 2005. 
BERGAMIN FILHO, A.; KIMATI, H.; AMORIN, L. Manual de fitopatologia. 3. ed. São Paulo: Agronômica Ceres, 1995. 919 p.

BHUIYAN, N. H. et al. Gene expression profiling and silencing reveal that monolignol biosythesis plays a critical role in penetration defense in wheat against powdery mildew invasion. Journal of Experimental Botany, Lancaster, v. 60, p. 509-521, 2009a.

BHUIYAN, N. H. et al. Role of lignification in plant defense. Plant Signaling \& Behavior, Nebraska, v. 4, p. 158-159, 2009 b.

BOESEWINKEL, H. J. Identification of Erysiphaceae by conidial characteristics. Revue de Mycologie, Paris, v. 41, 493-507, 1977.

BOESEWINKEL, H. J. The morphology of imperfect states of powdery mildew (Erysiphaceae). The Botanical Review, New York, v.46, p.167-224, 1980.

BRASIL. Ministério da Agricultura. Agrofit: sistema de agrotóxicos fitossanitários. Brasília, DF, 2009. Disponível em: < http://agrofit.agricultura.gov.br/agrofit_cons/principal_agrofit>. Acesso em: 30 abr. 2009.

BÜSHAGES, R. et al. The barley Mlo: a novel control element of plant pathogen resistance. Cell, Cambridge, v. 88, p. 695-705, 1997.

BUTT, D. J. Epidemiology of powdery mildew. In: SPENCER, D. M. The powdery mildews. New York: Academic, 1978. p. 51-77.

CARVALHO, O. T. Carotenóides e composição centesimal de ervilhas (Pisum sativum L.) cruas e processadas. 2007. 79 f. Dissertação (Mestrado em Ciência dos Alimentos)Faculdade de Ciências Farmacêuticas, Universidade de São Paulo, São Paulo, 2007.

CARVER, T. L. W; CARR, A. J. H. The early stages of mildew colony development on susceptible oats. Annals of Applied Biology, Oxford, v. 89, p. 201- 209, 1978.

CARVER, T.L.W. et al. Inhibition of Blumeria graminis germination and germiling development within colonies of oat mildew. Physiological and Molecular Plant Pathology, London v. 58, p. 209-228, 2001. 
CHEN, C. Q. et al. Defence enzymes induced in cucumber roots by treatment with plant growth-promoting rhizobacteria (PGPR) and Pythium aphanidermatum. Physiological and Molecular Plant Pathology, London, v. 56, p. 13-23, 2000.

COELHO, M. V. S. et al. Severidade de oídio em abóbora híbrida sob diferentes lâminas de irrigação e níveis de nitrogênio. Fitopatologia Brasileira, Brasília, DF, v. 25, p. 157-160, 2000 .

COHEN, Y.; EYAL, H.; HANANIA, J. Utrastructure autofluorescence, callose deposition and lignification in suscetible and resistant muskmelon leaves infetem with the powdery mildew fungus Sphaerotheca fuliginea. Physiological and Molecular Plant Pathology, London, v. 36, p. 191-204, 1990.

COOPER, D. C. Embryology of Pisum sativum. Botanical Gazette, Chicago, n. 100, p. 123 $132,1938$.

COUSIN, R. Étude de la résistance a l'oïdium chez le pois. Annual. Amélior Plantes, Paris, v. 55, p. 93-97, 1965.

CUTOLO FILHO, A. A. Sobrevivência de caracteres agronômicos e tecnológicos em populações de ervilha (Pisum sativum) conduzidas pelo método Bulk. 2000. $70 \mathrm{f}$.

Dissertação (Mestrado em Agronomia/Agricultura)-Faculdade de Ciências Agronômicas, Universidade Estadual Paulista, Botucatu, 2000.

DEWITTE, A. et al. Resistance reactions in rose leaves against powdery mildew (Podophaera pannosa). Acta Horticulturae, The Hague, v. 751, p. 183-188, 2007.

DIXON, S. D. Powdery mildew of vegetable an allied crops. In: SPENCER, D. M. (Ed.). The powdery mildew. New York: Academic, 1978. p. 495-524.

DOORENBOS, J.; KASSAM, A. H. Yield response to water. Rome: FAO, 1979. 193 p. (Irrigation and drainage paper, 33).

EDWARDS, M. C.; AYRES, P. G. Cell death and cell wall papillae in the resistance of oaks species to powdery mildew disease. New Phytologist, Cambridge, v. 89. p. 411-418, 1981. 
FALLOON, R. E.; SUTHERLAND, P. W.; HALLET, I. C. Morphology of Erysiphe pisi on leaves of Pisum sativum. Canadian Journal of Botany, Ottawa, v. 67, p. 3410-3416, 1989.

FERNÀNDEZ-APARICIO, M. et al. Characterization of resistance mechanisms to powdery mildew (Erysiphe betae) in beet (Beta vulgaris). Phytopathology, Saint Paul, v. 99, p. 385389, 2009.

FERREIRA, J. M. Influência do teor de umidade do solo em diferentes estádios de desenvolvimento da ervilha (Pisum sativum L.). 1991. 65 f. Dissertação (Mestrado em Agronomia/Horticultura)-Faculdade de Ciências Agronômicas, Universidade Estadual Paulista, Botucatu, 1991.

FERREIRA, D.F. Manual do sistema Sisvar para análises estatísticas. Lavras, Universidade Federal de Lavras, 2000. 66p.

FILGUEIRA, F. A. R. Novo manual de olericultura: agrotecnologia moderna na produção e comercialização de hortaliças. 3. ed. Viçosa: UFV, 2007. 421 p.

FILGUEIRA, F. A. R. Novo manual de olericultura: agrotecnologia moderna na produção e comercialização de hortaliças. 3. ed. Viçosa: UFV, 2000. 402 p.

FILIPPETTI, A.; GIOVANNI, C.; MARZANO, C. F. Genetics and molecular study of powdery mildew. In: ITALIAN SOCIETY OF AGRICULTURAL GENETICS, 48., 2004. Proceedings... Italy: Joint Meeting Lecce, 2004. p. 15-18.

FLOR, H. H. Genetics of pathogenicity in Melampsora lini. Journal of Agricultural Research, Washington v. 73, p. 335-356, 1946.

FONDEVILLA, S. et al. Macroscopic and histological characterization of genes erl and er2 for powdery mildew resistance in pea. European Journal of Plant Pathology, Dordrecht, v. 115, p. 309-321, 2006.

FONDEVILLA, S. et al. Identification and characterization of sources of resistance to Erysiphe pisi Syd, in Pisum spp. Plant Breeding, Berlin, v. 126, p. 113-119, 2007 a. 
FONDEVILLA, S. et al. Identification of a new gene for resistance to powdery mildew in Pisum fulvum, a wilt relative of pea. Breeding Science, Tokyo, v. 57, p. 181-184, $2007 \mathrm{~b}$.

FONDEVILLA, S.; RUBIALES, D.; MORENO, M. T. Identification and validation of RAPD and SCAR markers linked to the gene Er3 conferring resistance to Erysiphe pisi DC in pea. Molecular Breeding, Dordrecht, v. 22, n. 2, p. 193-200, 2008.

FREIALDEHOVEN, A. et al. Nar-1 and Na-2, to loci required for Mla-12-specified racespecific resistance to powdery mildew in barley. Plant Cell, Rockville, v. 6, p. 983-994, 1994.

FRYE, C.; INNES, R. W. An Arabdopsis mutant with enhanced resistance to powdery mildew. Plant Cell, Rockville, v. 10, p. 947-956, 1998.

GIORDANO, L., B.; REIFSCHNEIDER, F., J. B. Resistência ao oídio (causado por Erysiphe pisi D.C.) em ervilha (Pisum sativum L. cv. Triofin). Horticultura Brasileira, Brasília, v.2, n.1, p.35-7, 1984.

GJETTING, T. et al. Differential gene expression in individual papilla-resistant and powdery mildew-infected barley epidermal cells. Molecular Plant-Microbe Interactions, East Lansing, v. 17, n. 7, p. 729-738, 2004.

GRITON, E. T. Pea breeding. In: BASSET, M. J. Breeding vegetable crops. Flórida: Avi, 1986. p. 283-319.

GRITON, E. T.; WIERZBICKA, B. An embryological study of a Pisum sativum x Vicia faba cross. Euphytica, Wageningen, v. 24, p. 277-284, 1975.

GRITTON, E.T.; EBERT, R. D. Interaction of planting date and powdery mildew on pea plant performance. American Society Horticulturae Science, Alexandria, v.100, p. 137-142, abr. 1975.

GUIMARÃES, A. L; SANTOS, J. R. M. Nota preliminar sobre o controle químico de oídio (Oidium sp.) em ervilha (Pisum sativum) no Brasil. Fitopatologia Brasileira, Brasília, DF, v. 16, p. 138-140, 1991. 
GUPTA, M. D.; SHARMA, B.; MISHRA, S. K. Genetics of powdery mildew resistance in pea (Pisum sativum L.). In: INTERNATIONAL FOOD LEGUME RESEARCH CONFERENCE, 2., 1992, Cairo. Programs and abstracts... Pullman: Washington State University, 1992. p. 59.

GUPTA, V. K.; RATHORE, P. K.; SINGH, J. M. Quantitative genetic analysis of powdery mildew resistance in pea. In: Proceedings of de European Association for Grain Legume Research. Copenhagen, 1995. 202 p.

HAGEDORN, D. J. (Org.). Compendium of pea diseases. 3rd ed. Minnesota: American Phytopathological Society, 1989. 57 p.

HAMMOND-KOSACK, K.; JONES, J. D. G. Responses to pathogens. In.: BUCHANAN, B.; GRUISSEM, W.; JONES, R. (Eds.). Biochemistry and molecular biology of plants. Rockville: American Society of Plant Biologits, 2000. p. 1102-1156.

HANNAI, S. M. Reação de linhagens de ervilha de vagens comestíveis (Pisum sativum $\mathbf{L}$. ) ao oídio (Erysiphe pisi DC.). 2001. 56 f. Dissertação (Mestrado em Agronomia/Proteção de Plantas)-Faculdade de Ciências Agronômicas, Universidade Estadual Paulista, Botucatu, 2001.

HARBORNE, J. B. Introduction to ecological biochemistry. San Diego: Academic, 1993. $318 \mathrm{p}$.

HARLAND, S. C. Inheritance of immunity to mildew in Peruvian forms of Pisum sativum. Heredity, New York, v. 2, p. 263-269, 1948.

HERINGA, R. J.; VANNOREL, A.; TAZELAAR, M. F. Resistance to powdery mildew in pea. Euphytica, Wageningen, v. 18, p. 163-169, 1969.

HIGGINS, C. M.; MANNERS, J. M.; SCOTT, K. J. Decrease in three messenger RNA species coding for chloroplast proteins in leaves of barley infected with Erysiphe graminis $\mathrm{f}$. sp. hordei. Plant Physiology, Stanford, v. 78, p. 891-894, 1985.

HIRATA, K. Notes on haustoria, hyphae and conidia of the powdery mildew fungus of barley, Erysiphe graminis f.sp. hordei. Memories of the Faculty Agriculture Niigata University, v. 6, p. 207-259, 1967. 
HOLLOWAY, P. J.; MACLEAN, D. J.; SCOTT, K. J. Electron transport in thylakoids isolated from barley leaves infected by powdery mildew fungus (Erysiphe graminis DC. ex Merat f. sp. hordei Marchal. New Phytologist, Cambridge, v. 120, p. 145-151, 1992.

HORSHAM, H. R. Powdery mildew of field pea: agriculture notes. Victoria: Grains Research \& Development Corporation, 2008. 2 p.

HOTO, F. V.; PASCHOLATI, S. F. Oídio (Sphaerotheca fuliginea) em folha de abobrinha de moita (Cucurbita pepo) exibindo prateamento: germinação de conídios, formação de apressórios e aspectos bioquímicos da fitotoxemia. Summa Phytopathologica, Botucatu, v. 26, p. 84-88, 2000.

HUCKELHOVEN, R. et al. Hypersensitive cell death and papilla formation in barley attacked by the powdery mildew fungus are associated with hydrogen peroxide but not with salicylic acid accumulation. Plant Physiology, Washington, v. 119, p. 1251-1260, 1999.

JOHNSON, L. E. B.; BUSHNELL, W. R.; ZEYEN, R. J. Defense patterns in nonhost higher plant species against two powdery mildew fungi. I Monocotyledonous species. Canadian Journal of Botany, Ottawa, v. 60, p. 1068-1083, 1981.

JØRGENSEN, J. H.; Discovery, characterization and exploitation of Mlo powdery mildew resistance in barley. Euphytica, Wageningen, v. 63, p. 141-152, 1992.

$\mathrm{KATOCH}, \mathrm{V}$. et al. Molecular mapping of pea powdery mildew resistance gene er 2 to pea linkage group III. Molecular Breeding, Dordrecht, Aug. 2009. Disponível em:

$<$ http://www.springerlink.com/content/f4284121501m3p49/>. Acesso em: 23 nov. 2009.

KIMATI, H. et al. Manual de fitopatologia. 4. ed. São Paulo: Agronômica Ceres, 2005. v. 2, $623 \mathrm{p}$.

KUMAR, H.; SINGH, R. B. Genetic analysis of adult plant resistance to powdery mildew in pea (Pisum sativum L.). Euphytica, Wageningen, v. 30, p. 147-151, 1981.

KUROZAWA, C.; PAVAN, M. A. Doenças das cucurbitáceas. In: KIMATI, H. et al. (Eds.). Manual de fitopatologia. São Paulo: Agronômica Ceres, 1997. v. 2, p. 325-337. 
LEBEDA, A.; REININK, K. Histological characterization of resistance in Lactuca saligna to lettuce downy mildew (Bremia lactucae). Physiological and Molecular Plant Pathology, London, v. 44, p. 125-139, 1994.

LIU, S. M.; O'BRIEN, L.; MOORE, S. G. A single recessive gene confers effective resistance to powdery mildew of field pea grown in northern New South Wales. Australian Journal of Experimental Agriculture, Melbourne, v. 43, p. 373-378, 2003.

MARQUES, M. R. C. Herança da resistência da ervilha (Pisum sativum L.) ao oído (Erysiphe pisi DC.). 1993. 66 f. Dissertação (Mestrado em Genética e Melhoramento)Universidade Federal de Viçosa, Viçosa, 1993.

MARX, G. A. Location of er proving elusive. Pisum Newsletter, Troy, v. 18, p. 39-41, 1986.

MARX, G. A. New linkage relations for chromosome III of Pisum. Pisum Newsletter, Troy, V. 3, p. 18-19, 1971.

MATIELLO, R. R.; BARBIERI, R. L.; CARVALHO, F. I. F. Resistência das plantas a moléstias fúngicas. Ciência Rural, Santa Maria, Santa Maria, v. 27, n. 1, p. 161-168, 1997.

MATSUMOTO, I.; ASADA, Y. A role of lignification-inducing factor in resistance induction demonstrated in Japanese radish downy mildew and cucumber anthracnose. Annual Phytopathological Society Japan, v. 50, p. 483-490, 1984.

McDOWELL, J. M.; DANGL, J. L. Signal transduction in the plant immune response. Trends in Biochemical Sciences, Amsterdan, v. 25, p. 79-82, 2000.

McGRATH, M. T.; THOMAS, C. E. Powdery mildew. In: ZITTER, T. A.; HOPKINS, D. L.; THOMAS, C. E. (Eds.). Compedium of cucurbit diseases. Saint Paul: American Phytopathological Society, 1998. p. 25-27.

MOERSCHBACHER, B. M. et al. Specific inhibition of lignification breaks hypersensive resistance of wheat to stem rust. Plant Physiology, Stanford, v. 93, p. 465-470, 1990. 
MOHAMMADI, M.; KAZEMI, H. Changes in peroxidase and polyphenol activity in susceptible and resistant wheat heads inoculated with Fusarium graminearum and inducedresistance. Plant Science, Limerick, v. 162, p. 491-498, 2002.

NICHOLSON, R. L.; HAMMERSCHMITT, R. Phenolic compounds and their role in disease resistance. Annual Review of Phytopathology, Palo Alto, v. 30, p. 369-389, 1992.

NIKS, R. E.; RUBIALES, D. Potentially durable resistance mechanisms in plants to specialised fungal pathogens. Euphytica, Wageningen, v. 124, p. 201-216, 2002.

ODREJ, M. et al. Utilization of afila types of pea (Pisum sativum L.) resistant to powdery mildew (Erysiphe pisi DC.) in the breeding programs. Plant Soil Environmental, Czech Republic, v. 49, n. 11, p. 481-485, 2003.

PARASHAR, R.; SINDHAN, G. S. Biochemical charges in resistant and susceptible varieties of pea in relation to powdery mildew disease. Progressive Horticulture, Chaubattia, v. 18, p. 135-137, 1986.

PASCHOLATI, S. F.; LEITE, B. Hospedeiro: mecanismos de resistência. In: BERGAMIN FILHO, A.; KIMATI, H.; AMORIM, L. (Eds.). Manual de fitopatologia: princípios e conceitos. São Paulo: Agronômica Ceres. 1995. p. 417-454.

PEREIRA, A. S. Ervilha: integração pesquisa/iniciativa privada. Informe Agropecuário, Belo Horizonte, n. 158, p. 52-64, 1989.

PIERCE, W. H. Resistance to powdery mildew in pea. Phytopathology, Saint Paul, v. 37, p. $21,1948$.

POULTER, R.; HARVEY, L.; BURRITT, D. J. Qualitative resistance to powdery mildew in hybrid sweet peas. Euphytica, Wageningen, v. 133, p. 349-358, 2003.

REIS, A.; VIEIRA, J. V.; BUSO, J. A. Avaliação de linhagens de melão do tipo Valenciano para resistência a Sphaerotheca fuliginea, Raça 1. Fitopatologia Brasileira, Brasília, DF, v. 27, p. 156, 2002. Suplemento. 
REIS, N. V. B. dos. O clima e a cultura da ervilha. Informe Agropecuário, Belo Horizonte, v. 4, n. 158 , p. 8-9, 1989.

RESSER, P. W.; HAGEDORN, D. J.; A method for quantitative inoculations with Erysiphe pisi to assess variation of infection efficiency on peas. Phytopathology, Saint Paul, v. 73, p. 1238-1240, 1983.

RODRIGUES, O. et al. Cadeia produtiva da cultura de aveia. In: REUNIÃO DA COMISSÃO SUL-BRASILEIRA DA AVEIA, 1998, Londrina. Palestras... Londrina: IAPAR, 1998. p. 4557.

RUBIALES, D.; CARVER, T. L. W. Defence reactions of hordeum chilense accessions to three formae speciales of cereal powdery mildew fungi. Canadian Journal of Botany, Ottawa, v. 78, p. 1561-1570, 2000.

RUBIALES, D.; NICKS, R. E. Low appressorion formation by rust fungi on Hordeum chilense lines. Phytopathology, Saint Paul, v. 82, p. 1007-1012, 1992.

RYALS, J. A. et al. Systemic acquired resistance. The Plant Cell, Rockville, v. 8, p. 1809$1819,1996$.

SAENZ, G. S.; TAYLOR, J. W.; GARGAS, A. 18S Rrna Gene sequences and supraordinal classification of Erysiphales. Mycologia, New York, v. 86, n. 2, p. 212-216, 1994.

SALES JÚNIOR, R. et al. Eficiência de difenoconazole no controle de oídio do melão.

Fitopatologia Brasileira, Brasília, DF, v. 27, p. 122, 2002. Suplemento.

SANTOS, J. R. M.; PESSOA, H. B. S. V.; GIORDANO, L. B. Resistência de campo a oídio (Oidium sp.) em germoplasma de ervilha (Pisum sativum). Fitopatologia Brasileira, Brasília, DF, v. 18, n. 1, p. 123-125, 1993.

SAXENA, J. K.; TRIPATHI, R. M.; SRIVASTAVA, R. L. Powdery mildew resistance in pea (Pisum sativum L.) Current Science, Columbus, v. 44, p. 746, 1975.

SCHNATHORST, W. C. Environmental relationships in the powdery mildews. Annual Review of Phytopathology, Palo Alto, v. 3, p. 343-366, 1965. 
SCHROEDER, W. T.; PROVVIDENTI, R. Breakdown of er resistence to powdery mildew in Pisum sativum. Phytopathology, Saint Paul, v. 55, p. 1051-1085, 1965.

SCHULZE-LEFERT, P.; VOLGEL, J. Closing the ranks to attack by powdery mildew. Trends in Plant Science, Oxford, v. 5, n. 8, p. 343-348, 2000.

SHARMA, B. The Pisum genus has only one recessive gene for powdery mildew resistance. Pisum Genetics, Troy, v. 35, 2003. 6 p. Disponível em: $<$ http://hermes.bionet.nsc.ru/pg/>. Acesso em: 30 abr. 2009.

SINGH, H. B.; SINGH, U. P. Reversible phototropism in conidial germ tubes of Erysiphe polygoni. Journal of Plant Diseases and Protection, v. 88, p. 626-630, 1981.

STADNIK, J.; RIVERA, M. C. Oídios. Jaguariúna: EMBRAPA Meio Ambiente, 2001. 484 p.

STRICKBERGER, M.W. Genetics. 2. ed. New York: The Macmillan Co., 1976, 880p.

TAIZ, L.; ZEIGER, E. Fisiologia vegetal. 3. ed. Porto Alegre: Artmed, 2004. 719 p.

TIMMERMAN, G. M.; FREW, T. J.; WEEDEN, N. F. Linkage analysis of er-1, a recessive Pisum sativum gene for resistance to powdery mildew fungus (Erysiphe pisi DC).

Theoretical and Applied Genetics, Berlin, v. 88, p. 1050-1055, 1994.

TIWARI, K. R. et al. Pathogenic variation in Erysiphe pisi, the causal organism of powdery mildew of pea. Canadian Journal of Plant Science, Ottawa, p. 267-271, 1997a.

TIWARI, K. R.; PANNER, G. A.; WARKENTIN, T. D. Inheritance of powdery mildew resistance in pea. Canadian Journal of Plant Science, Ottawa, v. 77, p. 307-310, $1997 \mathrm{~b}$.

VAID, A.; TYAGI, P. D. Genetics of powdery mildew resistance in pea. Euphytica, Wageningen, v. 96 p. 203-206, 1997. 
VILIJANEN-ROLLINSON, S. L. H. et al. Components of quantitative resistance to powdery mildew (Erysiphe pisi) in pea (Pisum sativum). Plant Pathology, London, v. 47, p. 137-147, 1998.

WALTERS, D. R.; AYRES, P. G. Changes in nitrogen utilization and enzyme activities associated with $\mathrm{CO} 2$, exchanges in healthy leaves of powdery mildew-infected barley. Physiological Plant Pathology, London, v. 23, p. 447-459, 1983.

WARKENTIN, T. et al. Melfort field pea. Canadian Journal of Plant Science, Ottawa, v. 80, p. 117-119, 2000.

WARNOCK, S. J.; HAGEDORN, D. J. Stigma receptivity in peas (Pisum sativum L.). Agronomy Journal, Madison, v. 46, p. 274-277, 1954.

WEEDEN, N. F.; PROVIDENTI, R. Availability of seed from breeding lines containing genes for resistance to powdery mildew, Fusarium wilt races 1 and 2 and least nine virus disease.

Pisum Newsletter, Troy, v. 30, p. 33, 1999.

WOLKO, B.; WEEDEN, N. F. Additional markers for chromosome 6. Pisum Newsletter, Troy, v. 22, p. 71-74, 1990.

YARWOOD, C. E. History and taxonomy of powdery mildews. In: SPENCER, D. M. The powder mildews. New York: Academic, 1978. p. 1-37.

YARWOOD, C. E. Powdery mildews. The botanical Review, v. 23, p. 235-293, 1957.

YARWOOD, C. E. Reversible phototropism of the germ tubes of clover powdery mildew. Phytopathology, Saint Paul, v. 22, p. 31, 1932.

ZEYEN, R. J. et al. Inhibiting ohenylalanine ammonia lyase and cynnmayl alcohol dehydrogenase supresses Mlal (HR) but not mlo5 barley powdery mildew resistance. Physiological and Molecular Plant Pathology, London, v. 47, p. 11-140, 1995.

ZEYEN, R. J.; CARVER, T. L. W.; LYNGKJAER, M. F. Epidermal cell papillae. In.: BELANGER, R. R.; BUSHNELL, W. R. (Eds.). The powdery mildews: a comprehensive treatise. Saint Paul: APS, 2002. p. 107-125. 